\title{
The Transcriptional Activator Hypoxia Inducible Factor 2 (HIF-2/EPAS-1) Regulates the Oxygen-Dependent Expression of Erythropoietin in Cortical Astrocytes
}

\author{
Juan C. Chavez, ${ }^{1,2}$ Oxana Baranova, ${ }^{1}$ Janice Lin, ${ }^{1}$ and Paola Pichiule ${ }^{3}$ \\ ${ }^{1}$ Burke Medical Research Institute, White Plains, New York 10605, 2Department of Neurology and Neuroscience, Weil Medical College of Cornell University, \\ New York, New York 10021, and 3Department of Pediatrics, Morgan Stanley Children's Hospital, Columbia University, New York, New York 10032
}

In the ischemic or hypoxic brain, astrocytes appear to be one of the main sources of erythropoietin (EPO). In this study, we investigated the differential contribution of hypoxia inducible factor (HIF) isoforms to the regulation of hypoxic EPO expression in cultured astrocytes. In addition, using an in vitro model of oxygen-glucose deprivation (OGD), we studied the role of HIF-1 $\alpha$ and HIF-2 $\alpha$ in the generation of paracrine protective signals by astrocytes that modulate the survival of neurons exposed to 0GD. Expression of HIF-1 $\alpha$ or HIF- $2 \alpha$ was abrogated by infecting astrocytes with lentiviral particles encoding small interference RNA specific for HIF- $1 \alpha$ or HIF- $2 \alpha$ ( $\operatorname{siHIF-1} \alpha$ or siHIF- $2 \alpha$ ). Astrocytes infected with siHIF-1 $\alpha$ showed abrogated hypoxic induction of vascular endothelial growth factor (VEGF) and lactate dehydrogenase (LDH) but normal EPO induction. In contrast, reduction of HIF-2 $\alpha$ expression by siHIF-2 $\alpha$ led to a drastic decrease of EPO hypoxic expression, but it did not affect LDH or VEGF upregulation. To further test whether HIF-2 is sufficient to drive EPO upregulation, we expressed oxygen-insensitive mutant forms of HIF- $1 \alpha$ (mtHIF-1 $\alpha$ ) (P402A/P577A) and HIF-2 $\alpha$ (mtHIF- $2 \alpha)$ (P405A/P530A). Expression of mtHIF-2 $\alpha$ but not mtHIF-1 $\alpha$ in normoxic astrocytes resulted in a significant upregulation of EP0 mRNA and protein. Accordingly, HIF-2 $\alpha$ but not HIF-1 $\alpha$ was found to be associated with the EPO hypoxia-response element by a chromatin immunoprecipitation assay. Interestingly, conditioned medium from astrocytes challenged by sublethal OGD improved neuronal survival to OGD; however, this effect was abolished during the downregulation of astrocytic HIF- $2 \alpha$ using siHIF- $2 \alpha$. These results indicate that HIF- $2 \alpha$ mediates the transcriptional activation of EPO expression in astrocytes, and this pathway may promote astrocytic paracrinedependent neuronal survival during ischemia.

Key words: hypoxia; transcription; gene expression; EPO; astrocytes; HIF

\section{Introduction}

Erythropoietin (EPO) is a cytokine that regulates hematopoiesis, and, at the systemic level, it is produced mainly by interstitial fibroblasts in the kidneys of the adult and in hepatocytes in the fetus. Released into circulation, it reaches bone marrow in which it acts on Epo receptors (EPOR) promoting proliferation and differentiation of erythroid progenitors. Both EPO and EPOR are endogenously expressed in the CNS. In the developing brain, EPO and EPOR appear to play a role in early embryonic neurogenesis (Tsai et al., 2006). Accordingly, in vitro studies reveal that

\footnotetext{
Received June 8, 2006; revised July 31, 2006; accepted Aug. 1, 2006.

This work was supported in part by The W. Masterson Burke Foundation. J.C.C. is a recipient of a Transition to Independence Award from the Horace W. Goldsmith Foundation and Scientist Developing Award 0635556T from the Northeast affiliate of the American Heart Association. P.P. was supported by postdoctoral fellowship $0525870 T$ from the Heritage affiliate of the American Heart Association. We thank Dr. Rajiv Ratan and Dr. Jin Son for their invaluable support throughout this study, Dr. Ricardo Caceda (Emory University, Atlanta, GA) for his help with lentiviral vectors, Dr. M. Celeste Simon (University of Pennsylvania, Philadelphia, PA) for the generous gift of the expression vectors encoding stable mutant forms of mouse HIF- $1 \alpha$ (P402A/P577A) and HIF-2 $\alpha$ (P405A/P530A), and Dr. Randall Johnson (University of California, San Diego, La Jolla, CA) for providing the HIF-1 $\alpha$ conditional knock-out mice.

Correspondence should be addressed to Dr. Juan C. Chavez, Burke Medical Research Institute, 785 Mamaroneck Avenue, White Plains, NY 10605.E-mail: jchavez@burke.org or jcc2005@med.cornell.edu.

D0I:10.1523/JNEUROSCI.2838-06.2006

Copyright $\odot 2006$ Society for Neuroscience $\quad$ 0270-6474/06/269471-11\$15.00/0
}

EPO promotes neural stem cell proliferation, survival, and differentiation (Studer et al., 2000; Shingo et al., 2001). In the adult brain, the expression of EPO and EPOR persists in several regions, and hypoxic/ischemic insults trigger a robust augmentation of EPO expression (Digicaylioglu et al., 1995; Marti et al., 1996, 1997; Morishita et al., 1997; Bernaudin et al., 2000; Chikuma et al., 2000). Several studies have shown the EPO has potent neuroprotective properties in vivo and in vitro. EPO appears to have several biological effects, including direct protection of neurons and modulation of the angiogenic response. It has also been proposed that EPO signaling is important for adult neurogenesis and neuroblast migration to ischemic regions in vivo (Wang et al., 2004a,b; Tsai et al., 2006). At the cellular level, EPO expression is detected mainly in astrocytes and neurons. However, astrocytes appear to be the main source of EPO in the CNS because its expression both at the mRNA and protein level is far more robust compared with neurons (Masuda et al., 1994; Ruscher et al., 2002).

The hypoxia-induced upregulation of EPO expression is regulated at the transcriptional level by the hypoxia inducible factor (HIF) (Pugh et al., 1991; Maxwell et al., 1993; Bunn et al., 1998; Semenza, 1998; Ebert and Bunn, 1999; Fandrey, 2004). HIF is a heterodimer of HIF- $\alpha$ and HIF- $\beta$ subunits, which belong to the 
PAS (Per, Arnt, Sim) family of basic helix-loop-helix (bHLH) transcription factors (Wang et al., 1995; Semenza et al., 1997; Iyer et al., 1998b). The expression of the HIF- $\alpha$ subunit is regulated by oxygen levels, whereas the expression of the HIF- $\beta$ subunit, also known as arylhydrocarbon receptor nuclear translocator (ARNT), is constitutive and dimerizes with other bHLH-PAS transcription factors (Jiang et al., 1996; Pugh et al., 1997; Iyer et al., 1998a; Bruick, 2003). Currently, three HIF- $\alpha$ subunits [HIF$1 \alpha$, HIF-2 $\alpha$ /endothelial PAS domain protein 1 (EPAS- 1 ), and HIF- $3 \alpha$ ], as well as three HIF- $\beta$ subunits (HIF-1 $\beta$ /ARNT1, ARNT2, and ARNT3) are known. The most widely expressed $\alpha$ subunit in mammalian tissues is HIF- $1 \alpha$. The other HIF- $\alpha$ subunits appear to have more specialized and tissue-specific functions (Semenza, 2000). Recent studies have suggested that HIF- $2 \alpha$ rather than HIF- $1 \alpha$ might be responsible for hypoxiainduced EPO expression in the kidney as well as in hepatoma and neuroblastoma cell lines (Warnecke et al., 2004; Eckardt and Kurtz, 2005). In this study, we sought to determine the differential roles of HIF- $1 \alpha$ and HIF- $2 \alpha$ in the regulation of the hypoxiainduced expression of EPO as well as other oxygen-regulated genes in cultured cortical astrocytes.

In hypoxic astrocytes, EPO expression was downregulated by a small interference (si) RNA targeting HIF- $2 \alpha$ but not by an siRNA targeting HIF- $1 \alpha$. By chromatin immunoprecipitation (ChIP) assay, we found that HIF- $2 \alpha$ but not HIF- $1 \alpha$ was associated with the hypoxia-response element (HRE) of the Epo gene in hypoxic astrocytes. Moreover, the expression of a stable mutant form of HIF- $2 \alpha$ (mtHIF-2 $\alpha$ ) (P405A/P530A) was sufficient to activate EPO expression in normoxic astrocytes. As reported previously, conditioned medium from astrocytes (ACM) subjected to sublethal oxygen glucose deprivation (OGD) increased neuronal survival after a lethal OGD exposure; however, this effect was abolished during downregulation of astrocytic HIF- $2 \alpha$ using siHIF- $2 \alpha$. Together, our results indicate that HIF- $2 \alpha$ mediates the transcriptional activation of EPO expression in astrocytes, and this pathway may contribute to neuronal survival during ischemia via an astrocytic paracrine-dependent mechanism.

\section{Materials and Methods}

Animals. Mice carrying conditional HIF- $1 \alpha$ floxed alleles (HIF- $1 \alpha^{\mathrm{F} / \mathrm{F}}$ ) were generously provided by Dr. Randal Johnson (University of California, San Diego, La Jolla, CA). These animals (C57BL/6 genetic background) were generated by engineering LoxP sites flanking exon 2 of the HIF- $1 \alpha$ gene as described previously (Ryan et al., 2000). Age-matched wild-type black C57BL/6J mice were used as controls (The Jackson Laboratory, Bar Harbor, ME).

Neuronal cultures. Primary neuronal cultures were prepared from cerebral cortices of wild-type C57BL/6J or homozygote HIF- $1 \alpha$ conditional knock-out $\left(\mathrm{HIF}-1 \alpha^{\mathrm{F} / \mathrm{F}}\right.$ ) mouse embryos [embryonic day 15 (E15)], as described previously (Chavez and LaManna, 2002; Siddiq et al., 2005). Dissected cortices were dissociated at $37^{\circ} \mathrm{C}$ in Earl's balanced salt solution (EBSS) containing papain $(50 \mathrm{U} / \mathrm{ml})$ and DNase I (100 $\mathrm{U} / \mathrm{ml}$ ). The cell suspension was preplated in an uncoated T75 flask for $2 \mathrm{~h}$. The suspension was counted using the trypan blue exclusion method, and cells were plated at a density of $2 \times 10^{6} \mathrm{cells} / \mathrm{cm}^{2}$ in poly-D-lysinecoated plates $(50 \mathrm{mg} / \mathrm{ml})$ under serum-free conditions using Neurobasal medium supplemented with B27, glutamine $(2 \mathrm{mM})$, glutamate $(25 \mu \mathrm{M})$ (Invitrogen, Carlsbad, CA) and $25 \mathrm{~mm} \beta$-mercapthoethanol. On the fourth day of plating, one-half of the medium was replaced with glutamate-free B27/Neurobasal medium, and subsequently only glutamate-free medium was used to feed the cultures every $4 \mathrm{~d}$. Experiments were performed in cells at day in vitro (DIV) 12 . These cultures contained $>90 \%$ neurons as revealed by microtubule-associated protein-2 cytochemistry.

Astrocyte cultures. Primary cultures of astrocytes were prepared from cerebral cortices of 2-d-old C57BL/6J or homozygote HIF-1 $\alpha$ conditional knock-out (HIF-1 $\alpha^{\mathrm{F} / \mathrm{F}}$ ) mice following the same dissociation protocol described for neuronal cultures. Dissected cerebral cortices were dissociated at $37^{\circ} \mathrm{C}$ in EBSS containing papain $(50 \mathrm{U} / \mathrm{ml})$ and DNase I $(100 \mathrm{U} / \mathrm{ml})$. Cells were plated at a density of $1 \times 10^{6} \mathrm{cells} / \mathrm{cm}^{2}$ in $75 \mathrm{~cm}^{2}$ flasks coated with poly-D-lysine $(10 \mu \mathrm{g} / \mathrm{ml})$ in minimal essential media supplemented with $10 \%$ fetal bovine serum, $5 \%$ horse serum, glutamine (2 mM), and sodium bicarbonate (25 mM). At confluency (DIV 7), glial cultures were shaken for $8 \mathrm{~h}$ at $200 \mathrm{rpm}$ in a temperature-controlled incubator $\left(37^{\circ} \mathrm{C}\right.$; Barnstead, Dubuque, IA) to dislodge cells (i.e., microglia) that were loosely attached to the astrocyte monolayer. Cultures were maintained for an additional $3 \mathrm{~d}$, detached with $0.05 \%$ trypsin/EDTA (Invitrogen), plated in poly-D-lysine-coated $(10 \mu \mathrm{g} / \mathrm{ml})$ six-well dishes, and used at DIV 15 . These cultures contained $>95 \%$ astrocytes as revealed by the positive reaction of cells to an antibody against glial fibrillary acidic protein (GFAP).

Hypoxia and oxygen-glucose deprivation. For this purpose, we used a custom-made temperature-controlled hypoxic/anaerobic glove box (Coy Laboratories, Grass Lake, MI). For hypoxia treatments, the system was set up at $37^{\circ} \mathrm{C}$ with an atmosphere of $0.5 \% \mathrm{O}_{2}, 5 \% \mathrm{CO}_{2}$, and $94 \% \mathrm{~N}_{2}$, and all solutions were preequilibrated for at least $12 \mathrm{~h}$ before each experiment. Cells were transferred into the chamber, washed with PBS, and incubated with the appropriate media for up to $24 \mathrm{~h}$ in a humidified internal incubator. For OGD, the glove-box system was set up at $37^{\circ} \mathrm{C}$ with an atmosphere of $5 \% \mathrm{CO}_{2}, 5 \% \mathrm{H}_{2}$, and $90 \% \mathrm{~N}_{2}$ (anaerobic). All solutions were equilibrated for at least $12 \mathrm{~h}$. Cells were transferred into the chamber, washed with PBS, and incubated with a preequilibrated glucose-free balanced salt solution for up to $2 \mathrm{~h}$. At the end of the procedure, cells were removed from the chamber, fresh Neurobasal media were added (reperfusion), and the cultures were returned to a regular incubator. Cell death was assayed at $24 \mathrm{~h}$ after OGD measuring lactate dehydrogenase (LDH) released into the media. For experimental controls, we used cultures that were subjected to the same procedures but maintained with glucose-containing media at normoxia in a standard cell-culture incubator. The glove-box system used in this study was equipped with an inverted microscope that allowed us to visually inspect cell viability before terminating each experiment. All manipulations, including cell harvesting and cell lysis, were performed within the chamber.

Cell viability/cell death assays. Cell viability was assessed by propidium iodide (PI) uptake and retention of calcein (Invitrogen) using a Zeiss (Oberkochen, Germany)Axiovert 200M inverted epifluorescence microscope. Cultured neurons were rinsed with HBSS and incubated with 1 $\mu \mathrm{g} / \mathrm{ml}$ calcein-AM and $10 \mu \mathrm{g} / \mathrm{ml} \mathrm{PI}$ in the same buffer at $37^{\circ} \mathrm{C}$ for $20 \mathrm{~min}$. For cell counting, cells were rinsed with PBS and analyzed using a $20 \times$ objective lens. Calcein fluorescence was visualized using FITC filters (excitation, $488 \mathrm{~nm}$; emission, $515 \mathrm{~nm}$ ), and PI fluorescence was visualized using rhodamine filters (excitation, $536 \mathrm{~nm}$; emission, $645 \mathrm{~nm}$ ). Images were collected using a black and white Axiocam CCD camera. In a blind manner, a total of 10 randomly selected fields per condition were counted using the Axiovision Software (Zeiss). The magnitude of neuronal death was calculated by dividing the number of PI-positive cells by the sum of calcein-positive and PI-positive cells. In parallel experiments, cell viability was assessed by measuring release of $\mathrm{LDH}$ into the culture medium using the CytoTox 96 Non-Radioactive Cytotoxicity Assay kit (Promega, Madison, WI) following the protocol of the manufacturer.

siRNA-mediated gene silencing. For these experiments, we used a selfinactivating lentiviral vector system. Short RNA hairpins were cloned into the pLLV3.7 vector (American Type Culture Collection, Manassas, VA) under the control of the mouse polymerase-III U6-RNA gene promoter. This vector contains a cytomegalovirus (CMV)-enhanced green fluorescent protein (EGFP) expression cassette downstream of the U6 promoter that is used as a reporter gene to monitor infection efficiency (see Fig. 4A). RNA sequences targeting HIF- $1 \alpha$, HIF- $2 \alpha$, and $\beta$-galactosidase ( $\beta$-Gal) genes were designed as described previously and are listed in Table 1 (Aminova et al., 2005). Primary astrocytes were infected using media containing $50 \mathrm{ng} / \mathrm{ml}$ of the p24 antigen at DIV 15 and used $5 \mathrm{~d}$ later for all experiments.

Generation and titration of lentiviral particles. HEK293T cells were transfected with the pLL3.7 plasmid and packaging vectors using Lipo- 
Table 1. Hairpin oligonucleotide sequences for constructing siRNA specific for HIF- $1 \alpha$, HIF- $2 \alpha$, and $\beta$-galactosidase

\begin{tabular}{ll}
\hline Gene & Sequence \\
\hline HIF-1 $\alpha$ & $5^{\prime}$-TtGTGAGCTCACATCTTGATTTCAAGAGAATCAAGATGTGAGCTCACATTTTTT-3' \\
HIF-2 $\alpha$ & $5^{\prime}$-TCCTGTCCTTGATGCCTGACATTCAAGAGATGTGAGGCATCAAAGGACAGGTTTTT-3' \\
$\beta$-Gal & $5^{\prime}$-'TAAGGCCAGACGCGATTATTTTCAAGAGAAATAATTCGCGTCTGGCCTTTTTTTT-3'
\end{tabular}

Target sequences are underlined.

fectamine 2000 (Caceda et al., 2005). The second-generation human immunodeficiency virus (HIV)-based lentiviral packing vectors used were pCMV-dR8.91 and pVSV-G (generously provided by Dr. R. Caceda, Emory University, Atlanta, GA). The first plasmid (pCMVdR8.91) carries most of the HIV genome, except for the deleted accessory proteins. The second plasmid (pVSV-G) encodes a pseudotyped vesicular stomatitis virus capsule that confers extended tropism for any mammalian cell. After $36 \mathrm{~h}$, the supernatant was collected, the viral particles were recovered after ultracentrifugation $[25,000 \times g$ for $1.5 \mathrm{~h}$ in a Beckman Instruments (Fullerton, CA) SW28 rotor], and they were resuspended in PBS containing 10\% glycerol $(\sim 200 \mathrm{ml})$. Titers were determined by infecting 3T3 cells with serial dilutions of concentrated lentivirus and calculated by quantification of the p24 antigen (Retro-Tek HIV-1 p24 Antigen ELISA; Zeptometrix Corporation, Buffalo, NY). For a typical preparation, the titer was an average $6 \times 10^{8}$ infectious units per milliliter.

Cre recombinase-mediated HIF- $1 \alpha$ deletion. Cortical astrocytes derived from wild-type or homozygote HIF- $1 \alpha^{\mathrm{F} / \mathrm{F}}$ mice were prepared according to the procedure described above. At DIV 15, cells were infected with adenovirus encoding Cre recombinase under the control of the CMV promoter (Ad-Cre) or with an adenovirus encoding EGFP (Ad-GFP). Complete deletion of the floxed HIF- $1 \alpha$ alleles was accomplished after $4 \mathrm{~d}$ after infection as determined by Southern blotting and PCR. The following primers were use for PCR: forward, 5' AGCTACTGTAAATTTGGGGATGAA $3^{\prime}$; and reverse, 5' TGTTGGGGCAGTACTGGAAAGATG 3'. For all experiments, HIF- $1 \alpha$ null cells were used at DIV 20. For additional control experiments, cells isolated from wild-type mice were infected with Ad-Cre or Ad-GFP.

Preparation of whole-cell lysates and nuclear extracts. Cells were homogenized with a Dounce glass homogenizer using ice-cold lysis radioimmunoprecipitation assay buffer ( $1 \times$ PBS, $1 \%$ Nonidet P-40, $0.5 \%$ sodium deoxycholate, and $0.1 \%$ SDS) supplemented with protease inhibitors (Complete; Roche, Indianapolis, IN). Lysates were centrifuged at $10,000 \times g$ for $10 \mathrm{~min}$ at $4^{\circ} \mathrm{C}$, and supernatants were collected. Crude nuclear extracts were prepared as described previously (Chavez and LaManna, 2002) with minor modifications. Cells were harvested, washed with PBS, and centrifuged $(2000 \times g$ for $10 \mathrm{~min})$. The cell pellet was resuspended in 4 packed cell volume of buffer A (in mm: 10 Tris- $\mathrm{HCl}, \mathrm{pH}$ $7.5,1.5 \mathrm{MgCl} 2$, and $10 \mathrm{KCl}$ ), incubated on ice for $10 \mathrm{~min}$, and homogenized with a glass Dounce homogenizer. Nuclei were pelleted by centrifugation $\left(10,000 \times g\right.$ for $10 \mathrm{~min}$ at $\left.4^{\circ} \mathrm{C}\right)$ and resuspended in 3 packed nuclear volume of buffer C $(0.42 \mathrm{M} \mathrm{KCl}, 20 \mathrm{~mm}$ Tris- $\mathrm{HCl}, \mathrm{pH} 7.5,20 \% \mathrm{v} / \mathrm{v}$ glycerol, and $1.5 \mathrm{~mm} \mathrm{MgCl} 2)$. After rotation for $30 \mathrm{~min}\left(4^{\circ} \mathrm{C}\right)$, samples were centrifuged for $30 \mathrm{~min}$ at $15,000 \times g\left(4^{\circ} \mathrm{C}\right)$, and the supernatant (nuclear extract) was collected. Buffers A and C were freshly supplemented with DTT, $\mathrm{NaVO}_{4}$, and a protease inhibitor mixture (Complete; Roche). In all cases, protein concentrations were determined by a Bradford protein assay with bovine serum albumin used as standards (BioRad, Hercules, CA).

Western blot and ELISA analysis. Crude nuclear extracts (10 $\mu \mathrm{g}$ of protein) or cell lysates (25 $\mu \mathrm{g}$ of protein) were electrophoresed on SDSPAGE under reducing conditions and transferred to a nitrocellulose membrane (Bio-Rad) by standard procedures. Membranes were blocked with $5 \%$ nonfat dried milk and then incubated with the following primary antibodies: anti-HIF- $1 \alpha$, anti-HIF- $1 \beta$, and anti-HIF- $2 \alpha$ (Novus Biologicals, Littleton, CO); EPO and vascular endothelial growth factor (VEGF) (Santa Cruz Biotechnology, Santa Cruz, CA); neurofilament-68 (NF-68) and $\alpha$-tubulin (Chemicon, Temecula, CA); and $\beta$-actin and GFAP (Sigma, St. Louis, MO). After washing, membranes were incubated with the appropriate horseradish peroxidase-conjugated second- ary antibodies. Antigen-antibody complexes were visualized by enhanced chemiluminescence detection (ECL; Amersham Biosciences, Piscataway, NJ). Membranes were stripped and reprobed as needed.

Real-time PCR analysis. After indicated treatments, cells were harvested and total RNA was extracted using an RNA extraction kit (RNgents; Promega). Complementary DNA was synthesized from $2.5 \mu \mathrm{g}$ of total RNA using the Superscript III system with oligo-dT (18) primer (Invitrogen). Real-time PCR analysis was performed with $0.5 \mu \mathrm{l}$ of the final cDNA synthesis mix using mouse-specific Taq-Man-based gene expression assays (Applied Biosystems, Foster City, CA). The following assays were used: VEGF (catalog \#Mm00437304_m1), Epo (catalog \#Mm00433126_m1), LDH (catalog \#Mm00495282_g1), glucose transporter-1 (Glut-1) (catalog \#Mm00441473_m1), and $\beta$-actin (catalog \#Mm00607939_s1). The PCR reaction was performed in an ABI 7500 real-time PCR thermocycler (Applied Biosystems). All reactions were performed in duplicate using $\beta$-actin as an endogenous control. Experiments were independently repeated at least three times.

DNA electrophoretic mobility shift assay. Crude nuclear extracts $(5 \mu \mathrm{g}$ of proteins) were used for electrophoretic mobility shift assay (EMSA) to detect HIF-1 and HIF-2 DNA binding activity, as described previously (Aminova et al., 2005). Custom oligonucleotide probes (Invitrogen) corresponding to the hypoxia responsive element of the $3^{\prime}$ enhancer region of the Epo gene were annealed and radiolabeled with $\left[\gamma_{-}{ }^{32} \mathrm{P}\right]$ ATP using T4 polynucleotide kinase. After incubation with nuclear extracts, the DNA/protein complexes were resolved in $5 \%$ polyacrylamide gels, and the signal was visualized using a PhosphorImager (Fujifilm, Tokyo, Japan).

Chromatin immunoprecipitation assay and PCR amplification. Formaldehyde cross-linking and chromatin immunoprecipitation were performed as described previously (Orlando et al., 1997). Approximately $2 \times 10^{8}$ cells were used in each reaction. Cells were fixed in $10 \mathrm{ml}$ of PBS containing $1 \%$ formaldehyde for $15 \mathrm{~min}$ at room temperature. After washing three times with ice-cold PBS containing $1 \times$ protease inhibitors (Roche) and $1 \times$ phosphatase inhibitors (Sigma), cells were harvested and lysed in $2500 \mu \mathrm{l}$ of a solution containing $0.1 \%$ SDS, $0.5 \%$ Triton $\mathrm{X}-100,20 \mathrm{~mm}$ Tris- $\mathrm{HCl}, \mathrm{pH} 8.1$, and $150 \mathrm{~mm} \mathrm{NaCl}$ supplemented with protease and phosphatase inhibitors. The cross-linked chromatin suspension was sonicated 10 times ( $10 \mathrm{~s}$ pulses with $30 \mathrm{~s}$ rest periods) using a Sonicator 3000 (Mosonix, Farmingdale, NY) at output level 2 to generate $0.5-0.8 \mathrm{~kb}$ DNA fragments. The homogenates were centrifuged (5 $\mathrm{min}$ at $14,000 \times g$ ), and supernatants were collected and used for subsequent IP, followed by PCR analysis. For each sample, $100 \mu \mathrm{l}$ of supernatant was saved to determine proper DNA fragmentation by gel electrophoresis and to quantify the DNA input. The IP procedure was performed using a rotating mixer at $4^{\circ} \mathrm{C}$. Briefly, samples were precleared with normal rabbit IgG and protein G-magnetic beads (New England Biolabs, Beverly, MA) for $1 \mathrm{~h}$. IP was performed by mixing $500 \mu \mathrm{l}$ of precleared samples with $2.5 \mu \mathrm{g}$ of the following monoclonal antibodies: HIF- $1 \alpha$ and HIF- $2 \alpha$ (Novus Biologicals) and ARNT2 (Santa Cruz Biotechnology), followed by an overnight incubation. DNA-protein-antibody complexes were trapped by incubating each sample with protein $G$ magnetic beads and separated using a magnetic stand. The resulting pellets were sequentially washed in lysis solution containing 2 mM EDTA (two times for $10 \mathrm{~min}$ ), Li buffer containing $0.25 \mathrm{~mm} \mathrm{LiCl,} 1 \% \mathrm{NP}-40,1 \%$ deoxycholate, 1 mm EDTA, $10 \mathrm{~mm}$ Tris- $\mathrm{HCl}$, pH 8.1 (two times for 10 $\mathrm{min}$ ), and Tris-EDTA buffer, $\mathrm{pH} 8$ (two times for $10 \mathrm{~min}$ ). The protein $\mathrm{G}$ magnetic beads were released using a solution containing $1 \%$ SDS and $0.1 \mathrm{M} \mathrm{NaHCO}_{3}$ and separated by centrifugation $(2500 \times g$ for $5 \mathrm{~min})$. DNA-protein cross-linking was reversed by adding $10 \mathrm{ml}$ of $5 \mathrm{M} \mathrm{NaCl}$ to each sample, followed by an overnight incubation at $65^{\circ} \mathrm{C}$. DNA was isolated by phenol/chloroform/isoamyl alcohol (25:24:1) extraction, followed by ethanol precipitation, resuspended in $0.1 \mathrm{M}$ Tris- $\mathrm{HCl}, \mathrm{pH} 8$, and subjected to PCR analysis using primers indicated in Table 2.

Expression of stable forms of murine HIF-1 $\alpha$ and HIF-2 $\alpha$. The pcDNA3 plasmids encoding myc-tagged stable mutant forms of mouse HIF- $1 \alpha$ $(\mathrm{mtHIF}-1 \alpha)$ (P402A/P577A) and HIF-2 $\alpha$ (mtHIF-2 $\alpha$ ) (P405A/P530A) were generously provided by M. Celeste Simon (University of Pennsylvania, Philadelphia, PA). A pcDNA3.1 vector encoding the EGFP was used as a control. Mouse cortical astrocytes grown as described above for 
Table 2. Genomic primer sequences used for amplification of immunoprecipitated DNA samples from ChIP assays

\begin{tabular}{|c|c|c|c|c|}
\hline Gene & HIF binding site & Forward primer & Reverse primer & Product \\
\hline EPO & $5^{\prime}$ ttgggecctacgtgctgcctcg $3^{\prime}$ & $5^{\prime}$ agtgccctgccagaactgtaacca $3^{\prime}$ & $5^{\prime}$ caagcccagaggggtcaagaggt 3' & $469 \mathrm{bp}$ \\
\hline VEGF & $5^{\prime}$ cagtgcatacgtgggtttcca $3^{\prime}$ & $5^{\prime}$ ctgggcagctggectacctactt $3^{\prime}$ & $5^{\prime}$ gttagtcagtggcggggagtgaga $3{ }^{\prime}$ & $266 \mathrm{bp}$ \\
\hline LDH-A & $5^{\prime}$ ttccegcacgtccgctgggcteccac $3^{\prime}$ & $5^{\prime}$ cgggctcctgcttctgaggctgag 3' & $5^{\prime}$ cccacgcgtgcccaaatctgaac $3^{\prime}$ & $400 \mathrm{bp}$ \\
\hline Glut-1 & $5^{\prime}$ caggcgtgccgtctgacacgcatc $3^{\prime}$ & $5^{\prime}$ cctgcctgcgeccettacatc $3^{\prime}$ & $5^{\prime}$ catacccaaacccgeccctaccta $3^{\prime}$ & $469 \mathrm{bp}$ \\
\hline
\end{tabular}

These sequences were designed to amplify the HRE-containing region of the corresponding genes.

$\sim 12$ DIV were trypsinized and seeded on six-well tissue culture plates coated with poly-D-lysine $(10 \mu \mathrm{g} / \mathrm{ml})$ at a density of $50,000 \mathrm{cells} / \mathrm{cm}^{2}$. After $24 \mathrm{~h}$, subconfluent astrocytes (70-80\% confluency) were rinsed twice with Dulbecco's PBS and transfected with $8 \mu \mathrm{g}$ of endotoxin-free plasmids (Qiagen, Hilden, Germany) using Lipofectamine 2000 and OptiMEM (Invitrogen), following the protocol of the manufacturer. At $48 \mathrm{~h}$ later, the media were collected, and cells were harvested and used for ELISA, RNA isolation, and real-time PCR analysis. This protocol resulted in a transfection efficiency of $\sim 60 \%$.

Retroviral transduction of astrocytes. Murine leukemia virus-based retroviruses were generated in HEK293T cells (Harvard Gene Therapy Initiative, Boston, MA) by transfecting plasmids encoding a fusion protein of amino acids $1-529$ of HIF- $1 \alpha$ and the herpes simplex virus VP16 transactivation domain (pBABE-puro-HIF-1 $\alpha$-VP16) and a control plasmid encoding only VP16 (pBABE-puro-VP16) as described previously (Aminova et al., 2005). Retroviral transduction of wild-type cortical astrocyte cultures was accomplished by infecting cells plated in sixwell plates for $8 \mathrm{~h}$ in the presence of $4 \mu \mathrm{g} / \mathrm{ml}$ polybrene (Sigma). Fortyeight hours after infection, transduced astrocytes were selected with 2 $\mu \mathrm{g} / \mathrm{ml}$ puromycin for an additional $48 \mathrm{~h}$. One day later, the media were collected and cells were harvested and used for ELISA, RNA isolation, and real-time PCR analysis, respectively.

Immunohistochemistry. Wild-type 2-month-old male C57BL/6J mice (The Jackson Laboratory) were exposed to hypoxia $\left(8 \% \mathrm{O}_{2}\right)$ for $12 \mathrm{~h}$ in a Plexiglas chamber as described previously (Chavez et al., 2000; Chavez and LaManna, 2002). Littermate controls were kept under normoxia in a similar chamber for the duration of the experiment. Mice were killed with an overdose of pentobarbital, and brains were quickly removed from the skull and frozen in dry-ice chilled $\left(-70^{\circ} \mathrm{C}\right)$ isopentane. Coronal sections $(25 \mu \mathrm{m})$ were cut in a Leica (Nussloch, Germany) cryostat and mounted on Superfrost slides (VWR Scientific, West Chester, PA). Sections were fixed with ice-cold methanol $\left(-20^{\circ} \mathrm{C}\right)$ and incubated with PBS containing $0.4 \%(\mathrm{v} / \mathrm{v})$ Triton X-100 and $1 \%(\mathrm{w} / \mathrm{v})$ ELISA grade bovine serum albumin for $1 \mathrm{~h}$. Subsequently, sections were incubated overnight at $4^{\circ} \mathrm{C}$ with a rabbit polyclonal antibody against HIF- $2 \alpha(1$ : 200; Novus Biologicals). HIF- $2 \alpha$-positive cells were visualized with a biotinylated secondary anti-rabbit antibody, streptavidin-conjugated with horseradish peroxidase (HRP) and 3'diaminobenzidine (Vector Laboratories, Burlingame, CA). Sections were subsequently stained for the endothelial cell-specific marker CD31/PECAM-1 (platelet/endothelial cell adhesion molecule-1) using a rat anti-mouse CD31 antibody (1:100; eBioscience, San Diego CA). The signal was developed using a biotinylated anti-rat antibody, streptavidin-HRP, and NovaRED substrate (Vector Laboratories). An additional group of sections were stained for EPO using a polyclonal rabbit anti-EPO antibody (1:200; Santa Cruz Biotechnology) that was detected using an anti-rabbit antibody conjugated with Alexa-Fluor 564 (1:100; Invitrogen). Subsequently, sections were double stained for HIF- $2 \alpha$ using an anti-mouse antibody conjugated with Alexa Fluor 482 (1:100; Invitrogen). The staining was analyzed and documented using a Nikon (Tokyo, Japan) Eclipse $80 \mathrm{i}$ microscope.

Statistical analysis. Data are presented as mean \pm SD. Statistical comparisons among groups were made using a one-way ANOVA test with Tukey's correction. A $p<0.05$ was considered statistically significant.

\section{Results}

Expression of EPO in cultured cortical astrocytes and neurons subjected to hypoxia and hypoxia-mimetic agents

Primary cultures of neurons and astrocytes were exposed to normoxia, hypoxia $\left(0.5 \% \mathrm{O}_{2}\right)$, or treated with the pharmacological
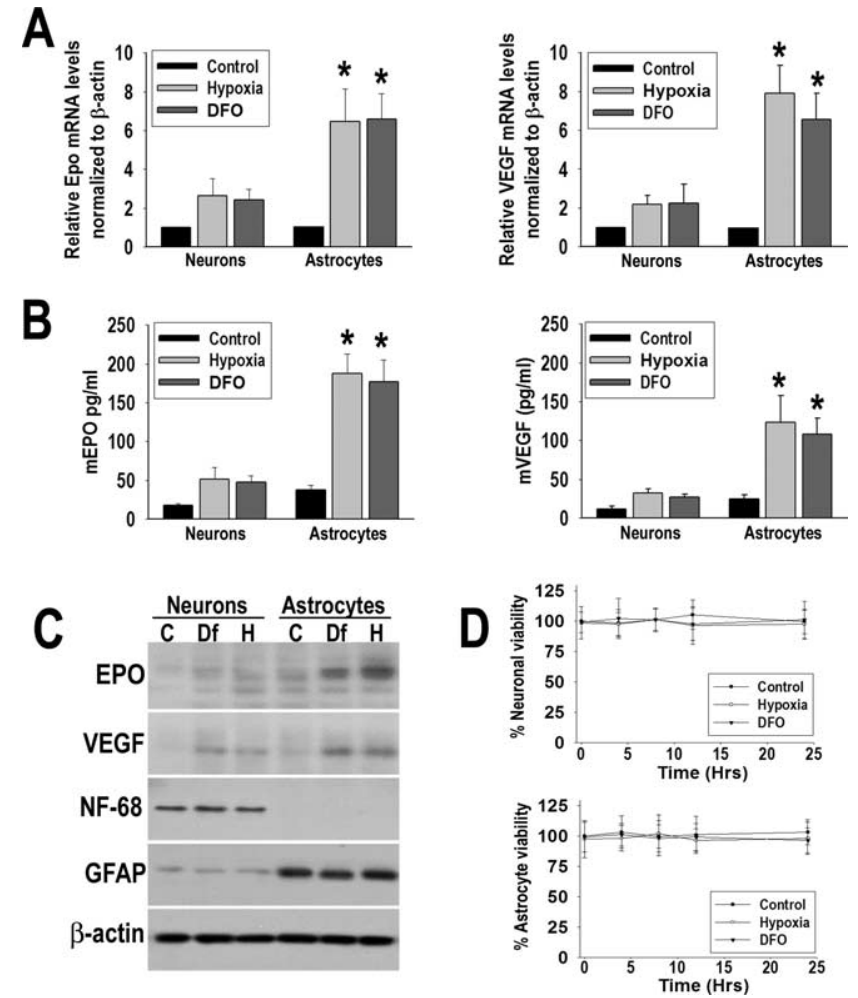

Figure 1. Differential expression of EPO and VEGF in neurons and astrocytes. $A$, Levels of Epo and VEGF $m R N A$ were assessed in primary cultures of astrocytes and neurons exposed to normoxia, $0.5 \% 0_{2}$, or DFO $(100 \mu \mathrm{m})$ for $24 \mathrm{~h}$ by real-time RT-PCR. Results were expressed as fold induction compared with cells exposed to normoxia and normalized to $\beta$-actin mRNA. B, ELISA analysis of secreted EPO and VEGF in the conditioned media of neurons and astrocytes exposed for $24 \mathrm{~h}$ to the same experimental conditions as described in $A$. C, Representative immunoblots of Epo and VEGF in cell lysates derived from primary astrocytes and neurons exposed to normoxia (C), $0.5 \% \mathrm{O}_{2}(\mathrm{H})$, or desferrioxamine (Df; $100 \mu \mathrm{M}$ ) for $24 \mathrm{~h}$. Data are expressed as the mean \pm SD from three to four independent experiments. ${ }^{*} p<0.05$ compared with normoxia. $D$, Cell viability was assessed in neurons and astrocytes at different time points during exposure to normoxia, hypoxia, or desferrioxamine using the LDH release assay.

HIF inducer desferrioxamine mesylate (DFO) $(100 \mu \mathrm{M})$ for $24 \mathrm{~h}$. Evaluation of EPO and VEGF mRNA levels by quantitative reverse transcription (RT)-PCR showed that both transcripts were upregulated by hypoxia or DFO in neurons and astrocytes compared with normoxic controls. However, induction of these transcripts was more prominent in astrocytes (Fig. $1 A$ ). We next assessed whether increased EPO and VEGF mRNA levels resulted in a parallel increase of the corresponding proteins. ELISA analysis showed almost a fivefold increase of secreted EPO and VEGF in astrocytes exposed to hypoxia or DFO compared with the twofold to threefold increase found in neurons (Fig. $1 \mathrm{~B}$ ). In addition, immunoblot analysis showed enhanced levels of EPO and VEGF protein levels in whole-cell lysates of astrocytes exposed to hypoxia or DFO compared with normoxia, but this induction was less prominent in neurons (Fig. 1C). Thus, at least in cultured conditions, astrocytes showed higher upregulation of VEGF and 
Epo than neurons in response to hypoxia or DFO. These findings could not be explained by differences in cell death rate because both cell types showed $>95 \%$ viability after 24 h of hypoxia or DFO treatments (Fig. 1D). Immunoblot analysis for GFAP and NF-68 revealed that neuronal cultures had low levels of glial cells present, whereas astrocyte cultures did not show evidence of neuronal presence (Fig. 1C).

Distinct expression of HIF-1 $\alpha$ and HIF- $2 \alpha$ protein in cortical astrocytes and neurons subjected to hypoxia and hypoxiamimetic agents

Considering that both VEGF and EPO are targets of the family of HIF transcription factors, we proceeded to compare the expression of HIF- $1 \alpha$ and HIF- $2 \alpha$ in astrocytes and neurons. HIF- $1 \alpha$ and HIF- $2 \alpha$ protein accumulation was analyzed in crude nuclear extracts prepared from astrocytes and neurons incubated under normoxic and hypoxic conditions or treated with the hypoxiamimetic agent DFO $(100 \mu \mathrm{M})$ for $4 \mathrm{~h}$. In neurons, protein levels of HIF- $1 \alpha$ and to a lesser degree HIF- $2 \alpha$ increased in response to hypoxia $\left(1 \% \mathrm{O}_{2}, 24 \mathrm{~h}\right)$ or DFO $(100 \mu \mathrm{M}, 24 \mathrm{~h})$. Conversely, in astrocytes exposed to hypoxia or DFO, induction of HIF- $2 \alpha$ was more prominent than HIF- $1 \alpha$ induction. The constitutive expression of HIF- $\beta$ (ARNT2) was not affected in either neurons or astrocytes (Fig. $2 A$ ).

HIF DNA binding activity in cultured cortical astrocytes and neurons subjected to hypoxia and hypoxia-mimetic agents To analyze HIF-specific DNA biding activity, we performed EMSA using nuclear extracts prepared from neurons or astrocytes exposed to hypoxia for $4 \mathrm{~h}$ and incubated with a ${ }^{32} \mathrm{P}$ radiolabeled 35 bp probe containing the HRE of the mouse Epo gene (Fig. $2 B$ ). EMSA analysis showed hypoxia-inducible binding activity in both cell types, as well as a constitutive binding activity present in both normoxic and hypoxic samples. The identity of the hypoxia-inducible complex was investigated by Supershift assays using antibodies raised against HIF- $1 \alpha$, HIF$2 \alpha$, ARNT2, or ARNT1. Supershift analysis revealed that, in neurons, the principal binding species appeared to be HIF- $1 \alpha$ and ARNT2, with apparently a lesser amount of HIF-2 $\alpha$ (Fig $2 B$, compare lanes 9,10$)$. In contrast, in astrocytes, the major binding species seems to be HIF- $2 \alpha$ and ARNT2, whereas HIF- $1 \alpha$ was present in a lesser amount (compare lanes 3,4). Together, these data suggest that astrocytes might rely preferentially on HIF- $2 \alpha$ to drive hypoxia-dependent EPO expression.

Cre recombinase-mediated deletion of HIF-1 $\alpha$ does not affect hypoxia-induced EPO expression in cortical astrocytes

Because astrocytes are the major sources of VEGF and EPO production in the hypoxic/ischemic brain, we wanted to further explore the differential role of HIF isoforms in the regulation of the expression of these genes. For this purpose, the expression of HIF- $1 \alpha$ or HIF- $2 \alpha$ was abrogated using different approaches, including Cre-mediated deletion (for HIF- $1 \alpha$ only) and siRNA. In the first approach, primary cultures of astrocytes were isolated from homozygous mice harboring lox-P sites flanking exon 2 of the HIF- $1 \alpha$ gene (HIF- $\left.1 \alpha^{\mathrm{F} / \mathrm{F}}\right)$ and transduced with Ad-Cre. Untreated astrocytes or astrocytes infected with Ad-GFP were used as controls. Preliminary experiments revealed that, at $2 \mathrm{~d}$ after infection, the majority of Ad-GFP-infected-cells expressed substantial levels of GFP (data not shown). In addition, RT-PCR analysis showed substantial Cre recombinase expression also at $2 \mathrm{~d}$ after transduction with Ad-Cre (data not shown). Infection of HIF- $1 \alpha^{\mathrm{F} / \mathrm{F}}$ astrocytes with Ad-Cre resulted in a time-dependent
A

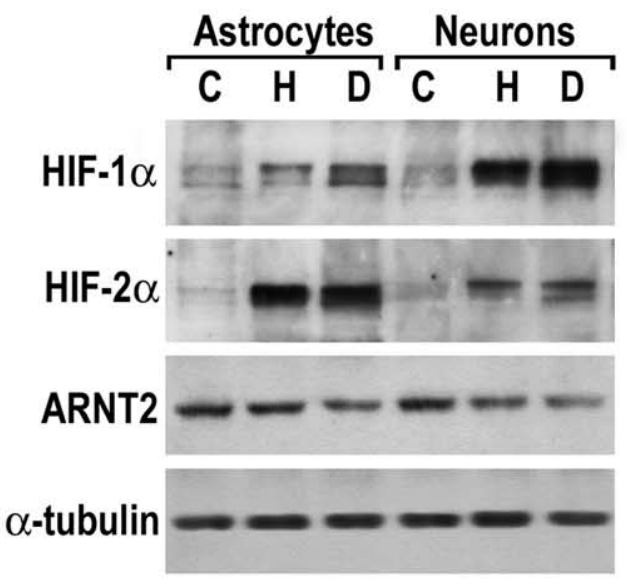

B

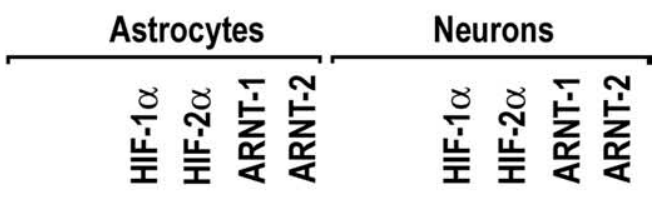

$1 \% \mathrm{O}_{2}-+++++-+++++$
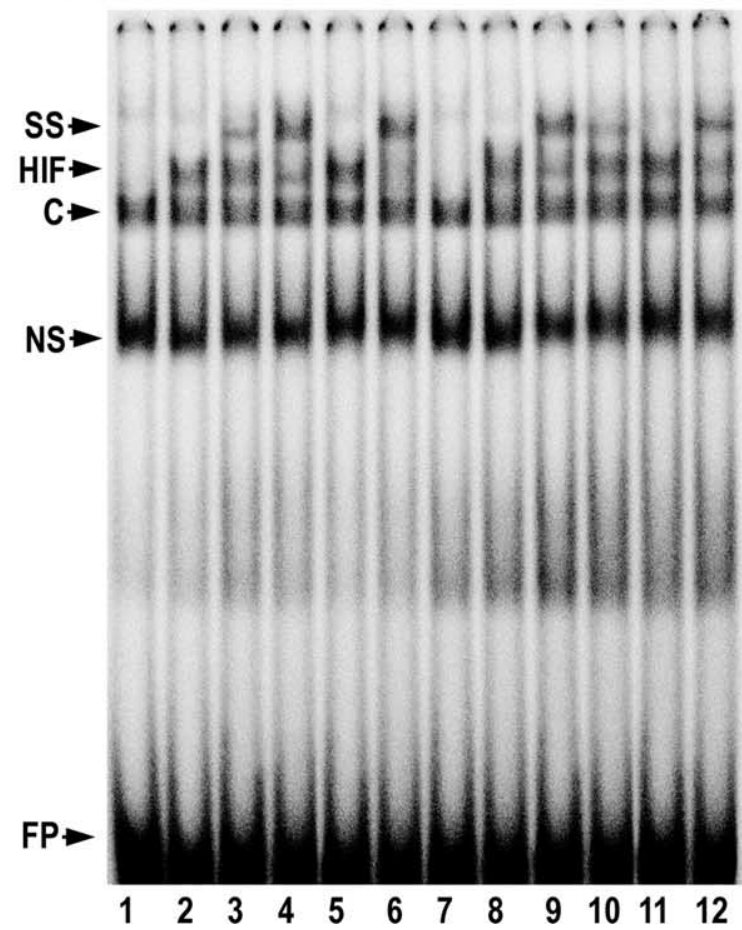

Figure 2. Expression of HIF- $1 \alpha$, HIF- $2 \alpha$, and ARNT2 in cultured neurons and astrocytes. $\boldsymbol{A}$, Western blot analysis of HIF- $1 \alpha$, HIF- $2 \alpha$, and ARNT2 in total cell lysates from primary cultures of neurons and astrocytes exposed to normoxia $(\mathrm{C})$, hypoxia $\left(\mathrm{H} ; 0.5 \% \mathrm{O}_{2}\right)$, or desferrioxamine ( $\mathrm{D}$; $100 \mu \mathrm{m}$ ) for 4 h. $\alpha$-Tubulin confirms equal amounts of protein loading. $\boldsymbol{B}$, Nuclear extracts from neurons and astrocytes exposed to normoxia or hypoxia $\left(4 \mathrm{~h}, 0.5 \% \mathrm{O}_{2}\right)$ were incubated with ${ }^{32} \mathrm{P}$-labeled oligonucleotides harboring Epo HREs. The resulting DNA-binding complexes were analyzed by EMSA. For Supershift assays, antibodies against HIF- $1 \alpha$ (lanes 3, 9), HIF- $1 \beta$ (lanes 4, 10), ARNT1 (lanes 5, 11), or ARNT2 (lanes 6, 12) were added to the binding reaction. C, Constitutive binding activity; NS, nonspecific binding; FP, free probe; SS, Supershift.

decline of the floxed HIF- $1 \alpha$ allele and a parallel increase of the Cre-mediated excision product (HIF-1 $\alpha^{\Delta}$ ), as revealed by PCR analysis of genomic DNA performed at $1-4 \mathrm{~d}$ after infection (Fig $3 A$ ). Efficient downregulation of HIF- $1 \alpha$ mRNA was confirmed 


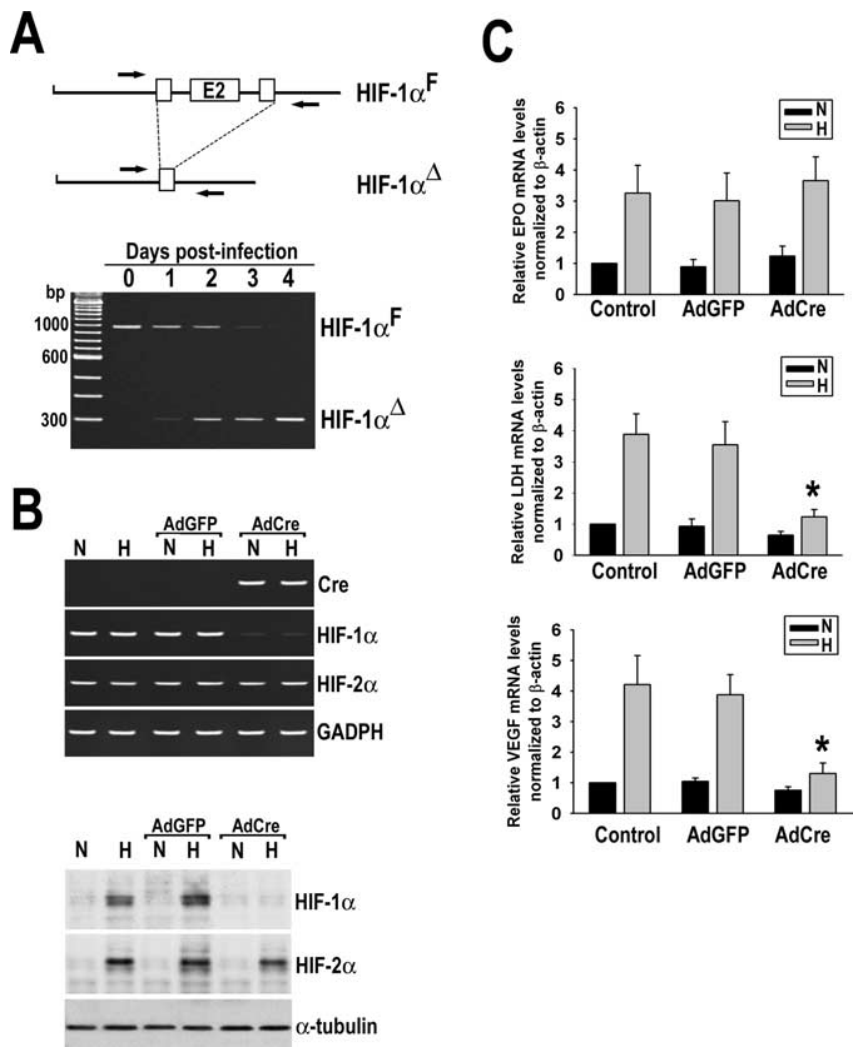

Figure 3. Cre recombinase-mediated deletion of the HIF- $1 \alpha$ allele in cultured astrocytes derived from double-floxed HIF- $1 \alpha$ transgenic mice. $A$, PCR analysis of the occurrence of Cremediated deletion of HIF- $1 \alpha$ in astrocytes isolated from HIF- $1 \alpha^{\mathrm{F} / \mathrm{F}}$ mice. At various time points after infection of astrocytes with Ad-Cre, DNA was extracted and PCR was performed with the primers indicated in the diagram. The amplified fragments correspond to the floxed HIF-1 $\alpha$ allele (HIF- $1 \alpha^{\mathrm{F}}$ ) and the HIF $1 \alpha$-deleted allele (HIF- $\left.1 \alpha^{\Delta}\right)$. B, HIF- $1 \alpha^{\mathrm{F} / \mathrm{F}}$ astrocytes were infected with Ad-GFP or Ad-Cre and 5 d later exposed to normoxia $(\mathrm{N})$ or hypoxia $(\mathrm{H})\left(0.5 \% \mathrm{O}_{2}\right.$ for $24 \mathrm{~h}$ ). Total RNA was extracted for RT-PCR analysis of (re recombinase, HIF- $1 \alpha$, HIF- $2 \alpha$, and glyceraldehyde-3-phosphate dehydrogenase (loading control) expression. In parallel experiments, nuclear extracts were prepared for immunoblot analysis of HIF- $1 \alpha$, HIF- $2 \alpha$, and $\alpha$-tubulin (loading control). C, HIF- $1 \alpha^{\mathrm{F} / \mathrm{F}}$ cortical astrocytes were subjected to the same experimental conditions as described in $\boldsymbol{B}$, and real-time RT-PCR was performed for EPO, LDH, VEGF, and $\beta$-actin (loading control). Data are expressed as the mean \pm SD from three to four independent experiments. ${ }^{*} p<0.05$ compared with non-infected hypoxic samples. Non-infected cells were denoted as Control.

by RT-PCR (Fig. 3B, top) at $5 \mathrm{~d}$ after infection in Ad-Cre-infected astrocytes. In addition, immunoblot analysis of Ad-Cre-infected astrocytes subjected to hypoxia $\left(24 \mathrm{~h}, 0.5 \% \mathrm{O}_{2}\right)$ demonstrated significant abrogation of hypoxic HIF- $1 \alpha$ induction (Fig $3 B$, bottom). Conversely, uninfected or Ad-GFP-infected astrocytes showed normal HIF- $1 \alpha$ mRNA levels and normal hypoxic induction of the HIF- $1 \alpha$ protein (Fig. $3 B$ ). As expected, HIF- $2 \alpha$ mRNA levels or the hypoxic induction of the HIF- $2 \alpha$ protein was not affected by Ad-Cre treatment. Interestingly, although the downregulation of HIF- $1 \alpha$ by Ad-Cre infection led to a drastic attenuation of the hypoxic induction of VEGF and LDH mRNA, two classic HIF-1 target genes, hypoxic induction of EPO mRNA during hypoxia was not affected (Fig $3 C$ ).

HIF-2 $\alpha$ /EPAS-1 knockdown by RNA interference prevents hypoxia-induced EPO expression in cortical astrocytes

Using a second approach to abrogate HIF, downregulation of HIF- $1 \alpha$ or HIF- $2 \alpha$ by RNA interference was achieved by infecting wild-type astrocytes at DIV 15 with a lentiviral vector encoding an HIF- $1 \alpha$ - or an HIF- $2 \alpha$-specific siRNA (siHIF- $1 \alpha$ or siHIF-
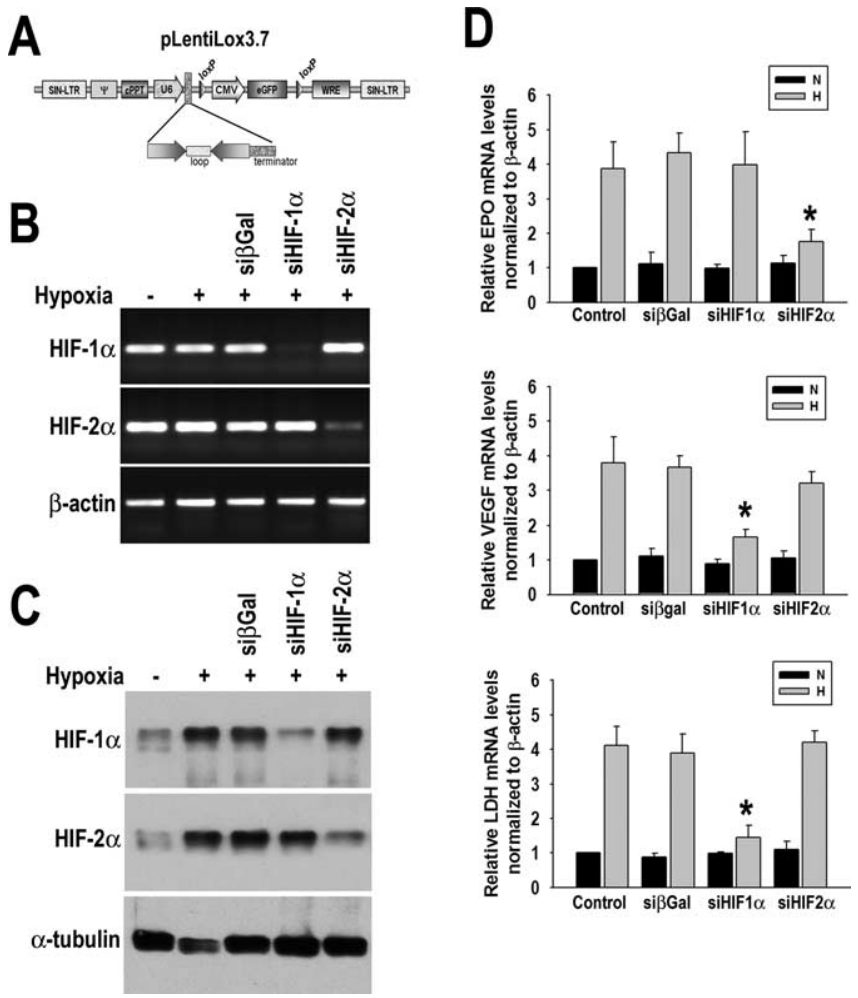

Figure 4. Downregulation of HIF- $1 \alpha$ and HIF- $2 \alpha$ by RNA interference. Cells were infected with lentivirus encoding siRNA against HIF- $1 \alpha$, HIF- $2 \alpha$, or $\beta$-gal. $\boldsymbol{A}$, A diagram of the pLL3.7 vector containing the EGFP reporter. At $5 \mathrm{~d}$ after infection, cells were exposed to normoxia or $0.5 \% \mathrm{O}_{2}$ for $24 \mathrm{~h}$, and total RNA or whole-cell lysates were prepared. $\boldsymbol{B}, \boldsymbol{C}$, The expression of HIF- $1 \alpha$ and HIF- $2 \alpha$ was evaluated by RT-PCR (B) and immunoblot analysis (C). D, The effect of siRNA-mediated downregulation of HIF- $1 \alpha$ and HIF- $2 \alpha$ on the expression of EPO, LDH, and VEGF was evaluated by real-time RT-PCR. Data are expressed as the mean \pm SD from three to four independent experiments. ${ }^{*} p<0.05$ compared with non-infected hypoxic samples. Noninfected cells were denoted as Control. N, Normoxia; $H$, hypoxia.

$2 \alpha$ ) (Fig. 4A). Efficient downregulation of the expression of HIF- $1 \alpha$ or HIF- $2 \alpha$ was confirmed by RT-PCR and Western blot analysis of infected cells exposed to hypoxia $\left(0.5 \% \mathrm{O}_{2}, 24 \mathrm{~h}\right)$. Importantly, siHIF- $1 \alpha$ did not affect the hypoxic expression of HIF- $2 \alpha$, whereas siHIF- $2 \alpha$ did not affect HIF- $1 \alpha$ hypoxic expression (Fig. $4 B, C$ ). The infection of astrocytes with control lentiviral particles encoding an siRNA specific for $\beta$-galactosidase ( $\mathrm{si} \beta$ Gal) did not affect hypoxic induction of HIF- $1 \alpha$ or HIF- $2 \alpha$. In agreement with our findings with Cre-mediated deletion of HIF$1 \alpha$, astrocytes infected with siHIF- $1 \alpha$ showed abrogated hypoxic induction of VEGF and LDH mRNA levels but normal EPO induction. Conversely, reduction of HIF- $2 \alpha$ expression by siHIF- $2 \alpha$ led to a drastic decrease of hypoxic EPO mRNA levels, but it did not affect LDH or VEGF hypoxic upregulation (Fig. $4 D$ ). Together, our data indicate that HIF- $2 \alpha$ is part of a mechanism governing the transcriptional activation of EPO in astrocytes, whereas HIF- $1 \alpha$ controls LDH and VEGF expression.

\section{HIF-2 binds to the EPO promoter in cultured astrocytes}

The preceding results show that, in astrocytes, HIF- $2 \alpha$ but not HIF- $1 \alpha$ likely controls EPO expression during hypoxia. To directly test which isoform binds to the HRE of the endogenous Epo gene, we performed ChIP on wild-type (HIF-1 $\alpha^{\mathrm{F} / \mathrm{F}}$ ) or HIF-1 $\alpha$ deficient astrocytes (HIF-1 $\alpha^{\Delta / \Delta}$ ) subjected to different periods of hypoxia $(0-24 \mathrm{~h})$. Abrogation of HIF- $1 \alpha$ expression was achieved by infecting astrocytes derived from HIF- $1 \alpha^{\mathrm{F} / \mathrm{F}}$ animals 


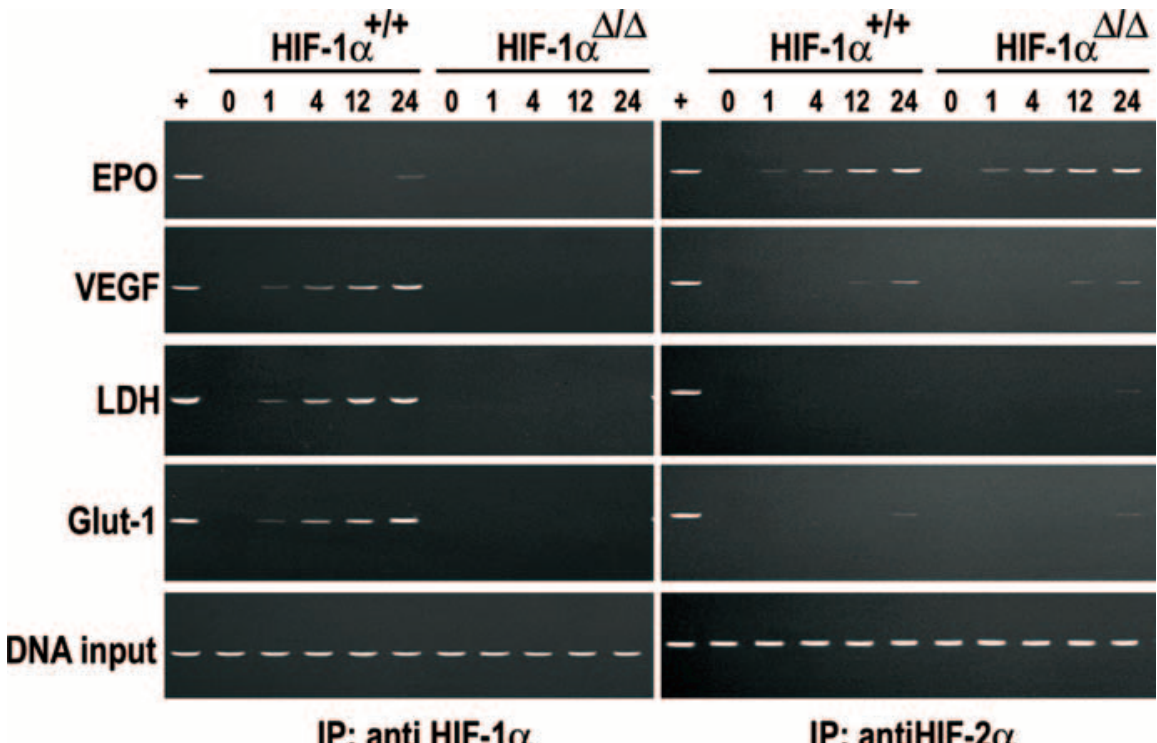

IP: anti HIF-1 $\alpha$

Figure 5. Endogenous HIF- $2 \alpha$ protein occupies the HREs of Epo in primary astrocytes as shown by ChIP assay. Anti-HIF-1 $\alpha$ and anti-HIF-2 $\alpha$ antibodies were used to precipitate the HIF- $\alpha$ proteins in nuclear extracts of cross-linked hypoxic HIF- $1 \alpha^{\mathrm{F} / \mathrm{F}}$ and HIF- $1 \alpha^{\Delta / \Delta}$ cells $(0.5 \% 0,0-24 \mathrm{~h})$. Coprecipitated DNA fragments were detected using PCR with primers specific for HREs of Epo, $V E G F, L D H$, and Glut-1. IP with anti-ARNT2 was performed in hypoxic HIF-1 $\alpha^{\mathrm{F} / \mathrm{F}}$ astrocytes as a positive control (+). HIF-1 $\alpha^{\Delta / \Delta}$ astrocytes were generated by Ad-Cre infection as described in Materials and Methods.

with Ad-Cre as described above. Immunoprecipitation of crosslinked DNA-protein complexes was performed using antiHIF- $1 \alpha$ or anti-HIF- $2 \alpha$ antibodies. The amount of cross-linked HRE-containing genomic DNA fragments derived from the EPO, VEGF, LDH, and Glut-1 enhancer/promoters regions that coprecipitated with either HIF- $1 \alpha$ or HIF- $2 \alpha$ was determined by PCR analysis. ChIP/PCR analysis revealed that, in astrocytes maintained under normoxic conditions, neither HIF- $1 \alpha$ nor HIF- $2 \alpha$ was significantly associated with the HRE region of the Epo gene. In contrast, in astrocytes exposed to $0.5 \% \mathrm{O}_{2}$ for several time points up to $24 \mathrm{~h}$, increasing amounts of genomic DNA fragments containing the Epo HRE were detected only when an anti-HIF- $2 \alpha$ antibody was used for immunoprecipitation of the DNA/protein complexes. When an anti-HIF- $1 \alpha$ antibody was used, no significant association of HIF- $1 \alpha$ with the Epo HRE region was observed. When we analyzed the promoter region of other hypoxia-responsive genes such as LDH, VEGF, and Glut-1, we observed the opposite result, a time-dependent recruitment of HIF- $1 \alpha$ rather than HIF- $2 \alpha$ to their corresponding HREs (Fig. 5). The specificity of this signal was confirmed by the absence of PCR amplicons in samples obtained from HIF- $1 \alpha$ null astrocytes $\left(\mathrm{HIF}-1 \alpha^{\Delta / \Delta}\right)$ that were subjected to immunoprecipitation using the anti-HIF- $1 \alpha$ antibody. Moreover, equivalent levels of PCR amplicon corresponding to the mouse Epo HRE were detected in samples obtained from hypoxic wild-type or HIF- $1 \alpha$ null (HIF$1 \alpha^{\Delta / \Delta}$ ) astrocytes after immunoprecipitation with the antiHIF- $2 \alpha$ antibody. As expected, ARNT2 protein, a binding partner for both HIFs, was found to interact with all of the target genes tested (Fig. 5, +). Together, the ChIP analysis demonstrated that HIF-2 $\alpha$ /EPAS-1 preferentially binds the astrocyte Epo 3' enhancer during hypoxia.

\section{Constitutive activation of HIF- $2 \alpha$ is sufficient to induce EPO expression}

To further confirm the role of HIF- $2 \alpha$ in the transcriptional regulation of EPO, we investigated the effect of overexpressing oxygen-insensitive mutant forms of HIF- $\alpha$ on EPO expression. These mutant proteins, named mtHIF- $\alpha$ (P402A/ P577A) and mtHIF-2 $\alpha$ (P405A/P530A), are constitutively expressed because of mutations in key proline residues required for oxygen-dependent degradation. Transient transfection of astrocytes with expression vectors encoding mtHIF- $1 \alpha$, mtHIF- $2 \alpha$, or GFP (control) under normoxic conditions resulted in the specific expression of the corresponding exogenous proteins (Fig. $6 E$ ). In agreement with our previous results, forced expression of mtHIF- $2 \alpha$ but not mtHIF- $1 \alpha$ resulted in an induction of EPO mRNA and protein levels, comparable with the effect of hypoxia (Fig. $6 A, B$ ).

To gain some insight into the molecular mechanism that prevents HIF-1, but not HIF-2, from binding to the EPO HRE and activating transcription, we did some experiments with astrocytes transduced with retroviral vectors encoding either VP16 alone or an HIF-1 $\alpha$-VP16 fusion protein. This fusion protein contains the human HIF- $1 \alpha$ DNA binding domain (1529 amino acids) and the herpes simplex virus VP16 transactivation domain. The HIF- $1 \alpha-\mathrm{VP} 16$ protein is stable under normoxia (Fig. 6E) because it lacks a prolyl residue at position 564 (equivalent of P577 in mouse), which is required for oxygendependent degradation. In contrast to the results obtained with mtHIF- $1 \alpha$, retroviral-mediated expression of HIF- $1 \alpha-$ VP16 in normoxic astrocytes led to induction of EPO mRNA and protein, comparable with the effect of hypoxia alone (Fig. 6C,D).

Cellular localization of HIF-2 $\alpha$ and EPO in the hypoxic brain We examined the cellular localization of HIF- $2 \alpha$ and EPO in the mouse brain during hypoxia $\left(8 \% \mathrm{O}_{2}\right.$ for $\left.24 \mathrm{~h}\right)$. Immunohistochemical analysis showed no detectable expression of HIF- $2 \alpha$ (Fig. 7A) and EPO expression (data not shown) in normoxic control brains. In the hypoxic brain, nuclear staining of HIF- $2 \alpha$ was evident throughout the brain (Fig. 7B). Expression of HIF- $2 \alpha$ was localized to nonvascular cells (Fig. 7C,E) and microvessels as demonstrated by double immunostaining with the endothelialspecific antigen CD31 (Fig. $7 D, F$, red). In agreement with previous reports (Bernaudin et al., 2000), expression of EPO was evident throughout the hypoxic brain and was mainly detected in astrocytes and microvessels (Fig. 8A). Interestingly, we found substantial colocalization of EPO-positive astrocytes and vessels with HIF-2 $\alpha$ (Fig. $8 B-D$ ). This finding supports an in vivo role of HIF- $2 \alpha$ in the control of EPO expression in astrocytes during hypoxia; however, it remains to be determined whether this is also true in endothelial cells.

\section{HIF-2-dependent factors secreted by astrocytes affect the} survival of neurons exposed to oxygen-glucose deprivation The secretion of EPO or other growth factors from astrocytes during ischemia can modulate the capacity of neurons to survive this stress (Ruscher et al., 2002). To address the role of astroglial HIFs in this protective cell-cell signaling mechanism, we tested the effect of conditioned medium from ischemic HIF null astrocytes on the survival of neurons exposed to OGD. We used a 


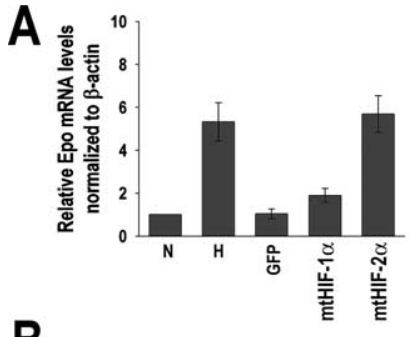

B
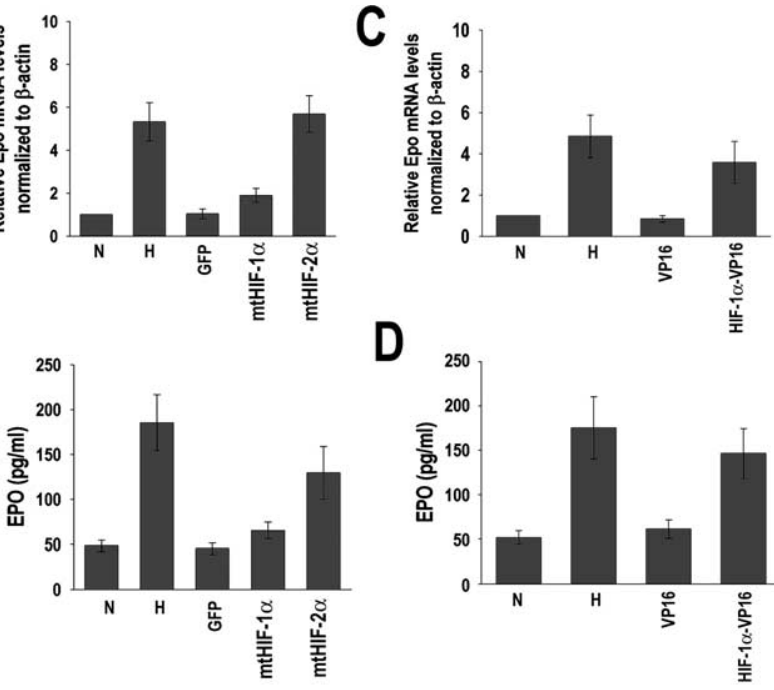

D
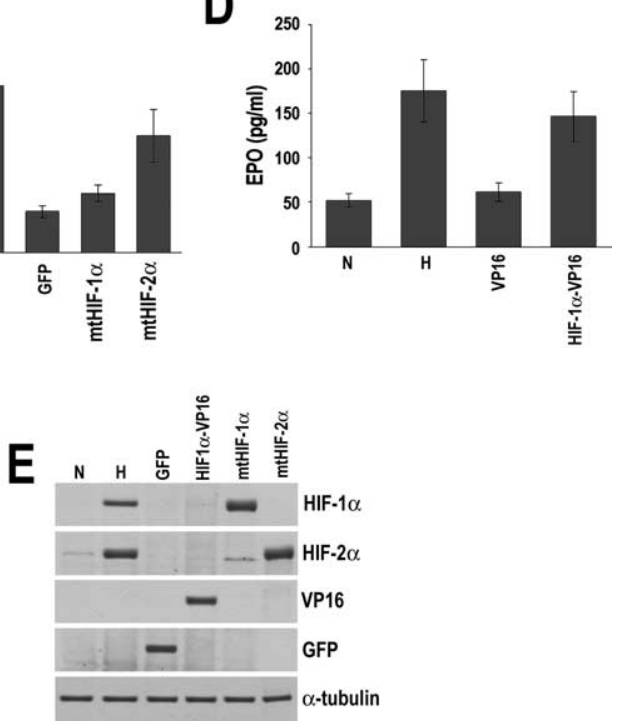

Figure 6. HIF-2 $\alpha$ is sufficient to activate EPO expression in astrocytes. $A, B$, Astrocytes were transiently transfected with expression vectors encoding mutant forms of HIF- $1 \alpha$ (mtHIF- $1 \alpha$, P402A/P577A) and HIF- $2 \alpha$ (mtHIF-2 $\alpha$, P405A/P530A) or GFP and maintained under normoxic conditions. C, D, Astrocytes were infected with retroviruses encoding either VP16 alone or HIF-1 $\alpha$-VP16 fusion protein. For comparison, nontransfected or non-infected astrocytes were exposed to normoxia (N) or $0.5 \% \mathrm{O}_{2}(\mathrm{H})$ for $24 \mathrm{~h}$. EPO mRNA and secreted EPO protein levels were evaluated by real-time RT-PCR $(\boldsymbol{A}, \boldsymbol{C})$ and ELISA $(\boldsymbol{B}, \boldsymbol{D})$, respectively. RT-PCR data of nontransfected normoxia (N) was used as a baseline. $\boldsymbol{E}$, Immunoblot analysis with antibodies against HIF- $1 \alpha$, HIF- $2 \alpha$, GFP, and VP16 confirmed the expression of transfected vectors. Data are expressed as the mean \pm SD from three to four independent experiments.

lentivirus-based strategy to downregulate HIF- $1 \alpha$ or HIF- $2 \alpha$ by RNA interference in primary astrocytes (as described in Fig. 4). At $5 \mathrm{~d}$ after transduction, astrocytes were subjected to sublethal OGD (60 min), and conditioned medium (ACM) was collected at $24 \mathrm{~h}$ of recovery. Preliminary experiments showed that this OGD condition did not affect the viability of wild-type or HIF null astrocytes (data not shown). Next, we tested whether ACM from OGD-stressed astrocytes could influence neuronal survival. For this purpose, neurons were pretreated with ACM for $6 \mathrm{~h}$ and then subjected to $120 \mathrm{~min}$ OGD. Figure 9 shows that OGD in untreated neurons led to $\sim 80 \%$ cell death, as measured by propidium iodide/calcein staining $24 \mathrm{~h}$ after the insult. Treatment of neurons with ACM derived from non-infected or lentivirus-si $\beta$ Gal-infected astrocytes resulted in the reduction of neuronal death ( $\sim 60 \%$ reduction) (Fig. $9 A)$. Not surprisingly, ACM derived from astrocytes with abrogated HIF- $2 \alpha$ expression (siHIF$2 \alpha$ ) showed a diminished efficacy preventing neuronal death $(\sim 15 \%$ reduction) (Fig. $9 A$ ). In comparison, ACM from siHIF$1 \alpha$-infected astrocytes was still efficient in reducing neuronal mortality (50\% reduction) (Fig. 9A). Previously, EPO has been identified as a component of the paracrine protective signaling pathway occurring from astrocytes to neurons (Ruscher et al., 2002). Accordingly, the addition of a neutralizing antibody against EPO to ACM significantly reduced its neuronal protective

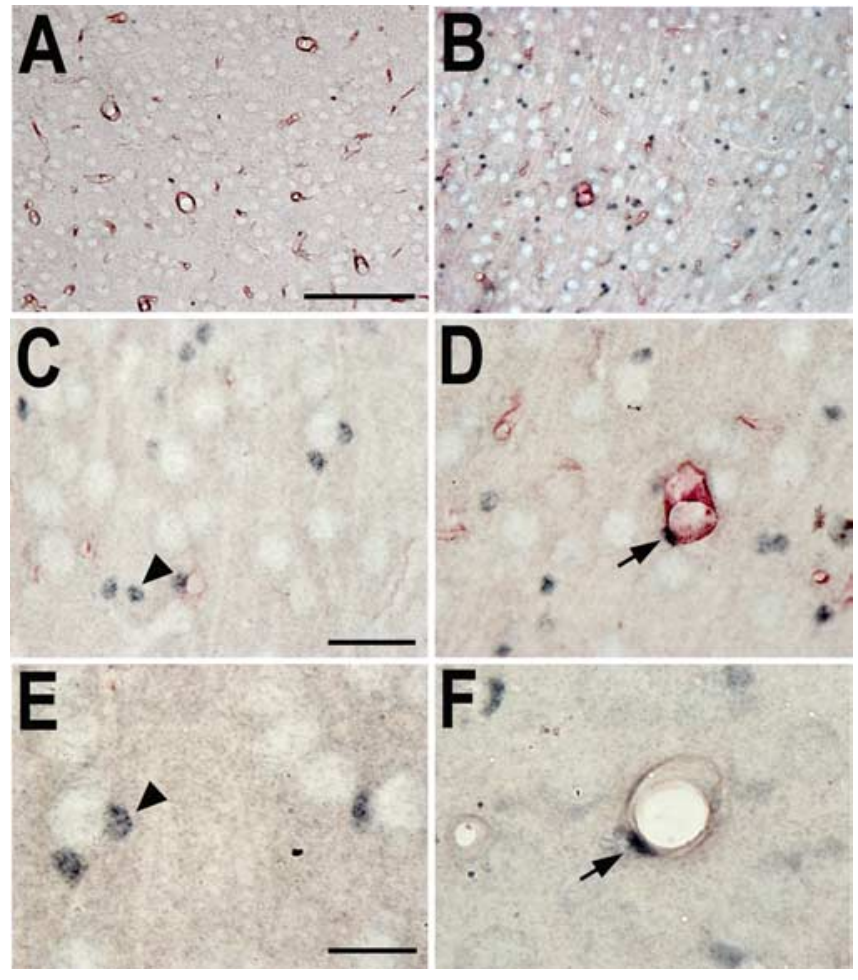

Figure 7. HIF-2 $\alpha$ immunohistochemistry in the hypoxic brain. $\boldsymbol{A}, \boldsymbol{B}$, Nuclear staining of HIF- $2 \alpha$ was detected in the hypoxic $(\boldsymbol{B})$ but not in the normoxic $(\boldsymbol{A})$ mouse brain. $\boldsymbol{D}, \boldsymbol{F}$, Double staining with the vessel marker $\mathrm{CD} 31$ (red) showed HIF-2 $\alpha$-positive nuclei associated with vessels (arrows). $\boldsymbol{C}, \boldsymbol{E}$, Nonvascular cells also showed HIF-2 $\alpha$ expression (arrowheads). Scale bars: $A, B, 25 \mu \mathrm{m} ; C, D, 10 \mu \mathrm{m} ; \boldsymbol{E}, \boldsymbol{F}, 5 \mu \mathrm{m}$.

properties (Fig. 9B). Conversely, supplementation of ACM derived from HIF- $2 \alpha$ null astrocytes with recombinant human EPO $(100 \mathrm{U} / \mathrm{ml})$ significantly improved neuronal survival. To further explore the role of astroglial HIF- $2 \alpha$ in this protective paracrine signaling, we tested the effect of ACM derived from astrocytes expressing mtHIF- $2 \alpha$ (as described in Fig. 6). Because mtHIF- $2 \alpha$ is constitutively expressed regardless of the oxygenation status, transfected astrocytes were cultured under normoxic conditions for $72 \mathrm{~h}$, and ACM was used for the treatment of neuronal cultures before exposure to OGD. Control astrocytes were transfected with a vector encoding GFP. Figure $9 C$ shows that ACM from astrocytes transfected with mtHIF- $2 \alpha$ improved survival of OGD-treated neurons ( $\sim 50 \%$ reduction of neuronal death) (Fig. 9C); however, addition of a neutralizing antibody against EPO reduced this prosurvival effect (Fig. 9C). ACM from GFPtransfected astrocytes had no effect on neuronal survival. The experiments described in Figure 9 were also repeated using the LDH release assay to assess neuronal death. This alternative approach confirmed the results obtained with the $\mathrm{PI} /$ calcein staining method (data not shown).

\section{Discussion}

It is well established that astrocytes support neuronal function and survival through multiple mechanisms. For instance, astrocytes release trophic factors that can protect neurons against several forms of injury (Ransom et al., 2003; Christopherson et al., 2005; Dienel and Hertz, 2005; Griffin et al., 2005; Hertz and Dienel, 2005; Nedergaard and Dirnagl, 2005). A key mediator of this paracrine neuroprotection is EPO, which acts via its cognate neuronal receptor (Ruscher et al., 2002). In cultured models, EPO-induced neuroprotection is effective within minutes and 

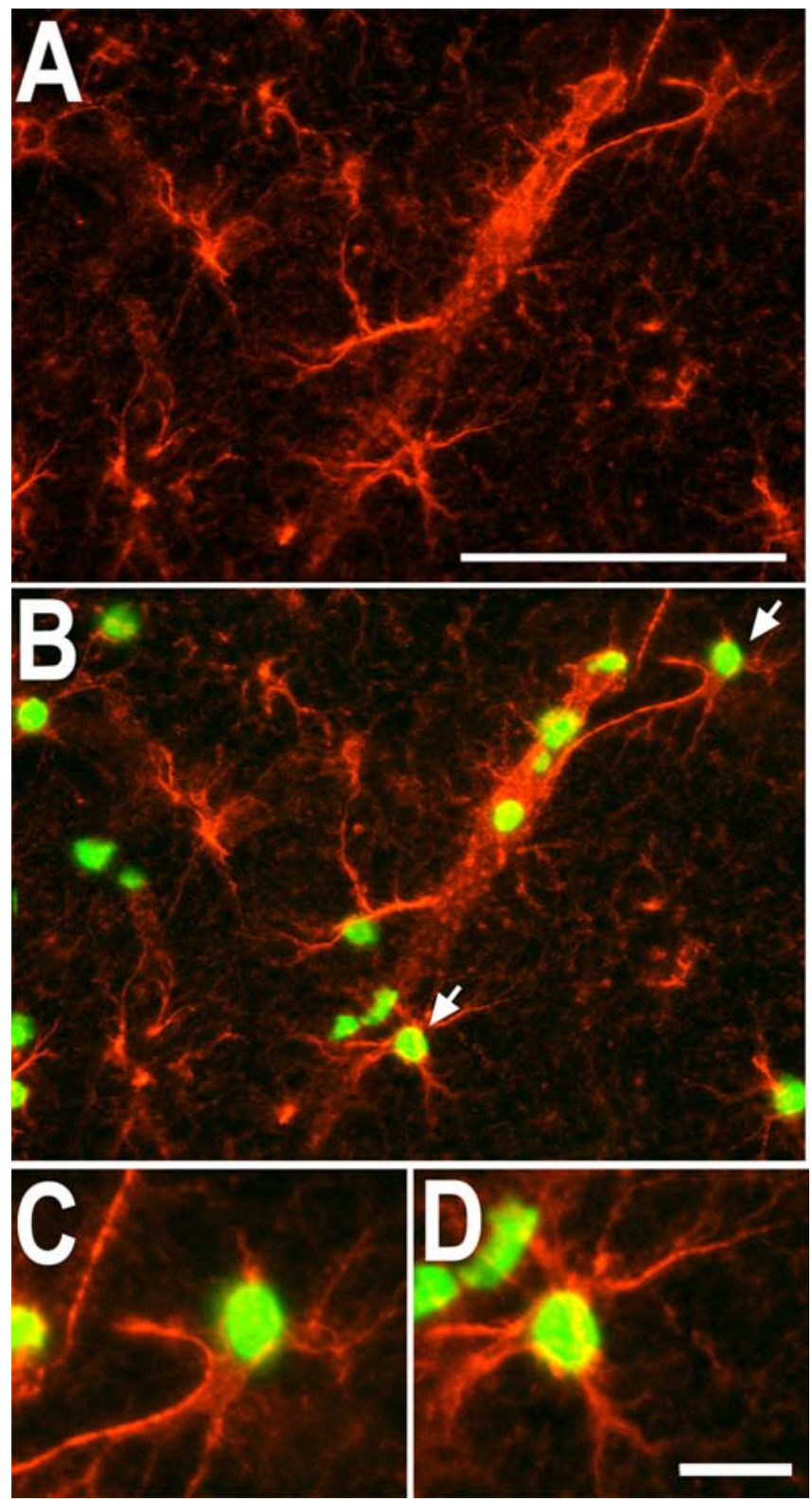

Figure 8. Colocalization of EPO and HIF-2 $\alpha$ expression. $A$, Immunohistochemical analysis of EPO in the mouse brain at $24 \mathrm{~h}$ of hypoxia (red). $\boldsymbol{B}-\boldsymbol{D}$, Merged images showing colocalization of HIF-2 $\alpha$-positive nuclei (green) and EP0-positive astrocytes and capillaries (red). Scale bars: $A$, $B, 25 \mu \mathrm{m} ; C, D, 5 \mu \mathrm{m}$.

can be sustained for many hours with continued EPO exposure. In addition, several studies with animal models have shown that EPO in the neonate and adult brain contributes significantly to neuroprotection and ischemic tolerance (Prass et al., 2002, 2003; Ruscher et al., 2002; Diaz et al., 2005; Hoke and Keswani, 2005; Liu et al., 2005). As expected, our data show that cultured neurons and astrocytes exposed to hypoxia are able to significantly upregulate EPO mRNA and protein levels. However, the upregulation of EPO mRNA and the secretion of the EPO protein into the media were significantly higher in astrocytes compared with neurons exposed to equal oxygen levels $\left(0.5 \% \mathrm{O}_{2}\right)$. Astrocytes also showed a more robust upregulation of VEGF in response to hypoxia compared with neurons. This disparity seems to fit the role ascribed to astrocytes as a source of trophic support for neurons.

In the adult hypoxic brain, the most ubiquitously expressed $\alpha$ subunit is HIF- $1 \alpha$. Several reports have confirmed the expression of HIF- $1 \alpha$ in neurons, astrocytes, endothelial cells, microglia, and oligodendrocytes (Bergeron et al., 1999; Chavez et al., 2000; Stroka et al., 2001). In contrast, as confirmed in this study, HIF- $2 \alpha$ expression is restricted to endothelial cells, astrocytes, and a subpopulation of neurons such as Purkinje cells (data not shown). Unlike in vivo, in cultured conditions, Western blot analysis showed that both the HIF- $1 \alpha$ and HIF- $2 \alpha$ proteins are present in cortical neurons and astrocytes, although their relative abundance appears to be different. HIF- $1 \alpha$ protein expression is more prominent in neurons, whereas HIF- $2 \alpha$ protein levels are higher in astrocytes. This discrepancy might be related to the developmental stage of the cultured neurons because they are derived from embryos (E15). Consistent with this finding, EMSA analysis revealed that, in astrocytes and neurons, both complexes, HIF- $1 \alpha$ /ARNT2 (HIF-1) and HIF-2 $\alpha$ /ARNT2 (HIF-2), appear to bind efficiently to the synthetic oligonucleotide containing the HIF binding sequence derived from the $3^{\prime}$ enhancer of the mouse Epo gene. Unlike neurons, in astrocytes, there was a preferential binding of HIF-2 rather than HIF-1. However, it is important to consider that this assay does not take into consideration the complexities of the endogenous DNA enhancer region or the coactivators that interact with the HIF complexes that are likely to influence their DNA binding specificity in vivo.

The contribution of HIFs to the regulation of hypoxiainduced gene expression has not being extensively studied in the context of the CNS. Despite Epo being considered one of the best characterized hypoxia-inducible genes, the specific contribution of HIF- $1 \alpha$ and HIF- $2 \alpha$ to the regulation of EPO expression remains unknown. In the present report, we explored this issue in cortical primary astrocytes, which are an important source of EPO production in vivo. We used several approaches to manipulate the expression of HIF- $1 \alpha$ and HIF- $2 \alpha$. First, we used cortical astrocytes isolated from a conditional knock-out mouse model in which exon 2 of the HIF- $1 \alpha$ gene is flanked by LoxP sites (Ryan et al., 2000). When these cells were infected with an adenovirus encoding Cre recombinase, HIF- $1 \alpha$ mRNA levels were significantly decreased and HIF- $1 \alpha$ protein accumulation was not detectable. In these HIF- $1 \alpha$ null astrocytes, the expression of Epo in response to hypoxia was maintained, whereas the hypoxia-driven upregulation of two known HIF-1 $\alpha$ target genes, LDH and VEGF, was decreased. In agreement with this finding, wild-type astrocytes that were infected with a lentiviral vector encoding an siRNA targeting HIF- $1 \alpha$ retained their ability to upregulate EPO expression during hypoxia, whereas the expression of VEGF and LDH was markedly reduced. In contrast, siRNA-mediated downregulation of HIF- $2 \alpha$ /EPAS- 1 expression in astrocytes subjected to hypoxia caused a significant reduction of EPO mRNA levels, whereas VEGF and LDH mRNA upregulation remained unaffected. These experiments provide strong evidence that, in cortical astrocytes, HIF- $2 \alpha$ /EPAS-1, but not HIF$1 \alpha$, is the main regulator of EPO expression during hypoxia. Additional support for the role of HIF-2 on EPO expression was provided by a ChIP assay, which indicated that, in hypoxic astrocytes, HIF- $2 \alpha$ rather than HIF- $1 \alpha$ is recruited to the $3^{\prime}$ enhancer region of the Epo gene that contains the HRE. These results are in agreement with previous studies that have provided evidence that Epo is an HIF-2 target gene (Warnecke et al., 2004; Eckardt and Kurtz, 2005). These studies relied also on siRNA technology to downregulate HIF- $1 \alpha$ and HIF- $2 \alpha$ expression in hepatoma (Hep3B and HepG2) and neuroblastoma (Kelly) cells that are know to secrete substantial amounts of EPO when challenged with hypoxia (Stolze et al., 2002). Furthermore, immunohisto- 
chemical studies have revealed that, in the hypoxic kidney, HIF- $2 \alpha$ but not HIF- $1 \alpha$ is expressed in the interstitial fibroblasts, which are the source of systemic EPO in adults (Eckardt and Kurtz, 2005).

We also determined the effect of the forced expression of proteasomeinsensitive mutant forms of the mouse HIF- $1 \alpha$ and HIF- $2 \alpha$ proteins on Epo expression. For this purpose, we used constructs in which the key proline residues responsible for HIF- $\alpha$ degradation during normoxia were mutated to alanines, mtHIF- $1 \alpha$ (P402A/P577A) and mtHIF-2 $\alpha$ (P405A/P530A) (Hu et al., 2003). In both cases, equal amounts of these expression vectors were transiently transfected into wild-type astrocytes. In agreement with our previous data, the expression of mtHIF- $2 \alpha$ was sufficient to induce a significant upregulation of EPO expression at both the mRNA and protein levels. In contrast, expression of mtHIF- $1 \alpha$ did not increases EPO expression but caused a robust upregulation of $\mathrm{LDH}$ and Glut-1 (data not shown). Interestingly, when the fusion protein HIF- $1 \alpha$-VP16 was expressed in astrocytes, we observed a significant upregulation of EPO expression. The apparent inconsistency of this result with the result obtained with the mtHIF-1 $\alpha$ expression could be attributed to the fact that HIF- $1 \alpha$-VP16 lacks the endogenous $\mathrm{N}$-terminus and C-terminus transactivation domains (NTAD and CTAD, respectively) of the full-length HIF- $1 \alpha$ molecule. The presence of these domains would play a role in preventing HIF- $1 \alpha$ binding to the Epo HRE and consequently its transcriptional activation. In the case of the HIF-1 $\alpha$-VP16 fusion protein, this constrain would be absent and HIF- $1 \alpha$-VP16 could bind the Epo HRE and activate its expression. Notably, the HIF- $\alpha$ subunits share an overall $50 \%$ homology in their protein sequence. This sequence and structure variability is very low in their $\mathrm{N}$-terminus portion that contains the DNA binding and dimerization domains but is high in their C-terminus region, which harbors both DNA transactivation domains (Hu et al., 2003). This feature suggests that HIF- $1 \alpha$ and HIF- $2 \alpha$ may interact with distinct transcriptional cofactors and have unique target genes even if both proteins are expressed in the same cell type. Thus, it is tempting to speculate that the NTAD and CTAD play an important role in defining the target genes for each HIF- $\alpha$ isoform.

In this report, we did not investigate the expression of the HIF- $3 \alpha$ subunit or its role in hypoxia-induced gene expression. In contrast to the HIF- $1 \alpha$ and HIF- $2 \alpha$ subunits, HIF- $3 \alpha$ is significantly upregulated at the mRNA level in the hypoxic brain (Heidbreder et al., 2003). However, its cellular localization and functional properties in the CNS are unknown. In this regard, we cannot exclude the possibility that HIF- $3 \alpha$ may contribute to the expression of Epo or other $\mathrm{O}_{2}$-regulated genes during hypoxia.

If HIF- $2 \alpha$ is the main transcriptional regulator of Epo expression during hypoxic conditions, then perhaps its role in neuroprotection is more relevant than HIF- $1 \alpha$. To gain some insight into the potential role of HIF- $2 \alpha$ in mediating astrocytedependent neuroprotection, we used a classic model of neuronal injury induced by oxygen-glucose deprivation that mimics ischemia (Monyer et al., 1992). Several studies have shown that ACM exposed to a sublethal period of OGD can protect neurons and that this effect is associated with EPO expression. Moreover, recombinant Epo was shown to be highly effective in reducing cell death after OGD (Digicaylioglu and Lipton, 2001; Digicaylioglu et al., 2004). In our experiments, we used astrocyte conditioned

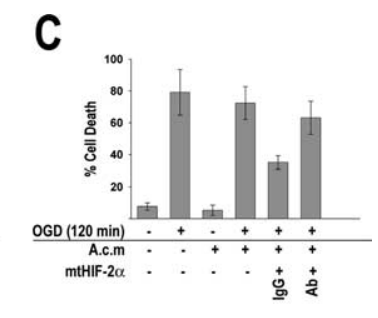

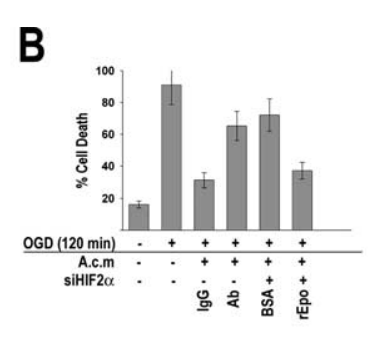
se prosurvival signaling of astrocytes to neurons. Cell death was measured using the propidium
hod. $A, B$, Percentage cell death was calculated in neuronal cultures that were pretreated with ACM and iodide/calcein staining method. $\boldsymbol{A}, \boldsymbol{B}$, Percentage cell death was calculated in neuronal cultures that were pretreated with $A C M$ and $24 \mathrm{~h}$ of reperfusion. When indicated, astrocytes were transduced with lentiviral vectors encoding si $\beta$-Gal, siHIF- $1 \alpha$, or siHIF- $2 \alpha$

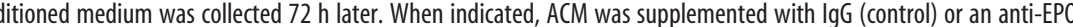

media from non-infected astrocytes as well as astrocytes infected with lentiviral vectors encoding $\beta$-Gal, HIF- $1 \alpha$, or HIF- $2 \alpha$ siRNAs. In agreement with previous reports, ACM was very effective in decreasing cell death in neuronal cultures subjected to a lethal OGD period (120 min). Neither $\beta$-Gal nor HIF- $1 \alpha$ siRNA had a major impact in this protective effect. However, ACM from cultures infected with siHIF- $2 \alpha$ showed a significant loss of this protective effect. Importantly, the effect of siHIF- $2 \alpha$ could be mimicked by a neutralizing antibody against EPO and could be rescued by supplementation with exogenous recombinant EPO. Finally, we showed that media from normoxic astrocytes that were transiently transfected with the stable mtHIF- $2 \alpha$ were also capable of conferring significant protection to neuronal cultures subjected to OGD. Importantly, this effect was reduced by a neutralizing EPO antibody.

In summary, we have shown that the hypoxia-induced expression of Epo is mediated primarily by HIF- $2 \alpha$ rather than HIF- $1 \alpha$. We have also shown that astrocytic HIF- $2 \alpha$ plays an important neuroprotective role, at least in cultured conditions, and that this effect is mediated by the upregulation of Epo expression.

\section{References}

Aminova LR, Chavez JC, Lee J, Ryu H, Kung A, LaManna JC, Ratan RR (2005) Prosurvival and prodeath effects of hypoxia-inducible factor- $1 \alpha$ stabilization in a murine hippocampal cell line. J Biol Chem 280:3996-4003.

Bergeron M, Yu AY, Solway KE, Semenza GL, Sharp FR (1999) Induction of hypoxia-inducible factor-1 (HIF-1) and its target genes following focal ischaemia in rat brain. Eur J Neurosci 11:4159-4170.

Bernaudin M, Bellail A, Marti HH, Yvon A, Vivien D, Duchatelle I, MacKenzie ET, Petit E (2000) Neurons and astrocytes express EPO mRNA: oxygen-sensing mechanisms that involve the redox-state of the brain. Glia 30:271-278

Bruick RK (2003) Oxygen sensing in the hypoxic response pathway: regulation of the hypoxia-inducible transcription factor. Genes Dev 17:2614-2623.

Bunn HF, Gu J, Huang LE, Park JW, Zhu H (1998) Erythropoietin: a model system for studying oxygen-dependent gene regulation. J Exp Biol 201:1197-1201

Caceda R, Kinkead B, Owens MJ, Nemeroff CB (2005) Virally mediated increased neurotensin 1 receptor in the nucleus accumbens decreases behavioral effects of mesolimbic system activation. J Neurosci 25:11748-11756.

Chavez JC, LaManna JC (2002) Activation of hypoxia-inducible factor-1 in the rat cerebral cortex after transient global ischemia: potential role of insulin-like growth factor-1. J Neurosci 22:8922-8931.

Chavez JC, Agani F, Pichiule P, LaManna JC (2000) Expression of hypoxiainducible factor- $1 \alpha$ in the brain of rats during chronic hypoxia. J Appl Physiol 89:1937-1942.

Chikuma M, Masuda S, Kobayashi T, Nagao M, Sasaki R (2000) Tissue- 
specific regulation of erythropoietin production in the murine kidney, brain, and uterus. Am J Physiol Endocrinol Metab 279:E1242-E1248.

Christopherson KS, Ullian EM, Stokes CC, Mullowney CE, Hell JW, Agah A, Lawler J, Mosher DF, Bornstein P, Barres BA (2005) Thrombospondins are astrocyte-secreted proteins that promote CNS synaptogenesis. Cell 120:421-433.

Diaz Z, Assaraf MI, Miller Jr WH, Schipper HM (2005) Astroglial cytoprotection by erythropoietin pre-conditioning: implications for ischemic and degenerative CNS disorders. J Neurochem 93:392-402.

Dienel GA, Hertz L (2005) Astrocytic contributions to bioenergetics of cerebral ischemia. Glia 50:362-388.

Digicaylioglu M, Lipton SA (2001) Erythropoietin-mediated neuroprotection involves cross-talk between Jak2 and NF- $\kappa \mathrm{B}$ signalling cascades. Nature 412:641-647.

Digicaylioglu M, Bichet S, Marti HH, Wenger RH, Rivas LA, Bauer C, Gassmann M (1995) Localization of specific erythropoietin binding sites in defined areas of the mouse brain. Proc Natl Acad Sci USA 92:3717-3720.

Digicaylioglu M, Garden G, Timberlake S, Fletcher L, Lipton SA (2004) Acute neuroprotective synergy of erythropoietin and insulin-like growth factor I. Proc Natl Acad Sci USA 101:9855-9860.

Ebert BL, Bunn HF (1999) Regulation of the erythropoietin gene. Blood 94:1864-1877.

Eckardt KU, Kurtz A (2005) Regulation of erythropoietin production. Eur J Clin Invest 35 [Suppl 3]:13-19.

Fandrey J (2004) Oxygen-dependent and tissue-specific regulation of erythropoietin gene expression. Am J Physiol Regul Integr Comp Physiol 286:R977-R988.

Griffin S, Clark JB, Canevari L (2005) Astrocyte-neurone communication following oxygen-glucose deprivation. J Neurochem 95:1015-1022.

Heidbreder M, Frohlich F, Johren O, Dendorfer A, Qadri F, Dominiak P (2003) Hypoxia rapidly activates HIF- $3 \alpha$ mRNA expression. FASEB J 17:1541-1553.

Hertz L, Dienel GA (2005) Lactate transport and transporters: general principles and functional roles in brain cells. J Neurosci Res 79:11-18.

Hoke A, Keswani SC (2005) Neuroprotection in the PNS: erythropoietin and immunophilin ligands. Ann NY Acad Sci 1053:491-501.

Hu CJ, Wang LY, Chodosh LA, Keith B, Simon MC (2003) Differential roles of hypoxia-inducible factor $1 \alpha$ (HIF- $1 \alpha)$ and HIF- $2 \alpha$ in hypoxic gene regulation. Mol Cell Biol 23:9361-9374.

Iyer NV, Kotch LE, Agani F, Leung SW, Laughner E, Wenger RH, Gassmann M, Gearhart JD, Lawler AM, Yu AY, Semenza GL (1998a) Cellular and developmental control of $\mathrm{O}_{2}$ homeostasis by hypoxia-inducible factor $1 \alpha$. Genes Dev 12:149-162.

Iyer NV, Leung SW, Semenza GL (1998b) The human hypoxia-inducible factor 1alpha gene: HIF1A structure and evolutionary conservation. Genomics 52:159-165.

Jiang BH, Rue E, Wang GL, Roe R, Semenza GL (1996) Dimerization, DNA binding, and transactivation properties of hypoxia-inducible factor 1 . J Biol Chem 271:17771-17778.

Liu J, Narasimhan P, Yu F, Chan PH (2005) Neuroprotection by hypoxic preconditioning involves oxidative stress-mediated expression of hypoxia-inducible factor and erythropoietin. Stroke 36:1264-1269.

Marti HH, Wenger RH, Rivas LA, Straumann U, Digicaylioglu M, Henn V, Yonekawa Y, Bauer C, Gassmann M (1996) Erythropoietin gene expression in human, monkey and murine brain. Eur J Neurosci 8:666-676.

Marti HH, Gassmann M, Wenger RH, Kvietikova I, Morganti-Kossmann MC, Kossmann T, Trentz O, Bauer C (1997) Detection of erythropoietin in human liquor: intrinsic erythropoietin production in the brain. Kidney Int 51:416-418.

Masuda S, Okano M, Yamagishi K, Nagao M, Ueda M, Sasaki R (1994) A novel site of erythropoietin production. Oxygen-dependent production in cultured rat astrocytes. J Biol Chem 269:19488-19493.

Maxwell PH, Pugh CW, Ratcliffe PJ (1993) Inducible operation of the erythropoietin $3^{\prime}$ enhancer in multiple cell lines: evidence for a widespread oxygen-sensing mechanism. Proc Natl Acad Sci USA 90:2423-2427.

Monyer H, Giffard RG, Hartley DM, Dugan LL, Goldberg MP, Choi DW (1992) Oxygen or glucose deprivation-induced neuronal injury in cortical cell cultures is reduced by tetanus toxin. Neuron 8:967-973.

Morishita E, Masuda S, Nagao M, Yasuda Y, Sasaki R (1997) Erythropoietin receptor is expressed in rat hippocampal and cerebral cortical neurons, and erythropoietin prevents in vitro glutamate-induced neuronal death. Neuroscience 76:105-116.

Nedergaard M, Dirnagl U (2005) Role of glial cells in cerebral ischemia. Glia 50:281-286.

Orlando V, Strutt H, Paro R (1997) Analysis of chromatin structure by in vivo formaldehyde cross-linking. Methods 11:205-214.

Prass K, Ruscher K, Karsch M, Isaev N, Megow D, Priller J, Scharff A, Dirnagl U, Meisel A (2002) Desferrioxamine induces delayed tolerance against cerebral ischemia in vivo and in vitro. J Cereb Blood Flow Metab 22:520-525.

Prass K, Scharff A, Ruscher K, Lowl D, Muselmann C, Victorov I, Kapinya K, Dirnagl U, Meisel A (2003) Hypoxia-induced stroke tolerance in the mouse is mediated by erythropoietin. Stroke 34:1981-1986.

Pugh CW, Tan CC, Jones RW, Ratcliffe PJ (1991) Functional analysis of an oxygen-regulated transcriptional enhancer lying $3^{\prime}$ to the mouse erythropoietin gene. Proc Natl Acad Sci USA 88:10553-10557.

Pugh CW, O’Rourke JF, Nagao M, Gleadle JM, Ratcliffe PJ (1997) Activation of hypoxia-inducible factor-1; definition of regulatory domains within the alpha subunit. J Biol Chem 272:11205-11214.

Ransom B, Behar T, Nedergaard M (2003) New roles for astrocytes (stars at last). Trends Neurosci 26:520-522.

Ruscher K, Freyer D, Karsch M, Isaev N, Megow D, Sawitzki B, Priller J, Dirnagl U, Meisel A (2002) Erythropoietin is a paracrine mediator of ischemic tolerance in the brain: evidence from an in vitro model. J Neurosci 22:10291-10301.

Ryan HE, Poloni M, McNulty W, Elson D, Gassmann M, Arbeit JM, Johnson RS (2000) Hypoxia-inducible factor- $1 \alpha$ is a positive factor in solid tumor growth. Cancer Res 60:4010-4015.

Semenza GL (1998) Hypoxia-inducible factor 1: master regulator of $\mathrm{O}_{2}$ homeostasis. Curr Opin Genet Dev 8:588-594.

Semenza GL (2000) Oxygen-regulated transcription factors and their role in pulmonary disease. Respir Res 1:159-162.

Semenza GL, Agani F, Booth G, Forsythe J, Iyer N, Jiang BH, Leung S, Roe R, Wiener C, Yu A (1997) Structural and functional analysis of hypoxiainducible factor 1. Kidney Int 51:553-555.

Shingo T, Sorokan ST, Shimazaki T, Weiss S (2001) Erythropoietin regulates the in vitro and in vivo production of neuronal progenitors by mammalian forebrain neural stem cells. J Neurosci 21:9733-9743.

Siddiq A, Ayoub IA, Chavez JC, Aminova L, Shah S, LaManna JC, Patton SM, Connor JR, Cherny RA, Volitakis I, Bush AI, Langsetmo I, Seeley T, Gunzler V, Ratan RR (2005) Hypoxia-inducible factor prolyl 4-hydroxylase inhibition. A target for neuroprotection in the central nervous system. J Biol Chem 280:41732-41743.

Stolze I, Berchner-Pfannschmidt U, Freitag P, Wotzlaw C, Rossler J, Frede S, Acker H, Fandrey J (2002) Hypoxia-inducible erythropoietin gene expression in human neuroblastoma cells. Blood 100:2623-2628.

Stroka DM, Burkhardt T, Desbaillets I, Wenger RH, Neil DA, Bauer C, Gassmann M, Candinas D (2001) HIF-1 is expressed in normoxic tissue and displays an organ-specific regulation under systemic hypoxia. FASEB J 15:2445-2453.

Studer L, Csete M, Lee SH, Kabbani N, Walikonis J, Wold B, McKay R (2000) Enhanced proliferation, survival, and dopaminergic differentiation of CNS precursors in lowered oxygen. J Neurosci 20:7377-7383.

Tsai PT, Ohab JJ, Kertesz N, Groszer M, Matter C, Gao J, Liu X, Wu H, Carmichael ST (2006) A critical role of erythropoietin receptor in neurogenesis and post-stroke recovery. J Neurosci 26:1269-1274.

Wang GL, Jiang BH, Rue EA, Semenza GL (1995) Hypoxia-inducible factor 1 is a basic-helix-loop-helix-PAS heterodimer regulated by cellular $\mathrm{O}_{2}$ tension. Proc Natl Acad Sci USA 92:5510-5514.

Wang L, Zhang Z, Wang Y, Zhang R, Chopp M (2004a) Treatment of stroke with erythropoietin enhances neurogenesis and angiogenesis and improves neurological function in rats. Stroke 35:1732-1737.

Wang L, Zhang Z, Zhang R, Hafner MS, Wong HK, Jiao Z, Chopp M (2004b) Erythropoietin up-regulates SOCS2 in neuronal progenitor cells derived from SVZ of adult rat. NeuroReport 15:1225-1229.

Warnecke C, Zaborowska Z, Kurreck J, Erdmann VA, Frei U, Wiesener M, Eckardt KU (2004) Differentiating the functional role of hypoxiainducible factor (HIF)- $1 \alpha$ and HIF- $2 \alpha$ (EPAS-1) by the use of RNA interference: erythropoietin is a HIF- $2 \alpha$ target gene in Hep3B and Kelly cells. FASEB J 18:1462-1464. 